San Jose State University

SJSU ScholarWorks

Master's Theses

Master's Theses and Graduate Research

Summer 2014

\title{
Vulnerability of Groundwater to Perchloroethylene Contamination from Dry Cleaners in the Niles Cone Groundwater Basin, Southern Alameda County, California
}

Anne C. Jurek

San Jose State University

Follow this and additional works at: https://scholarworks.sjsu.edu/etd_theses

\section{Recommended Citation}

Jurek, Anne C., "Vulnerability of Groundwater to Perchloroethylene Contamination from Dry Cleaners in the Niles Cone Groundwater Basin, Southern Alameda County, California" (2014). Master's Theses. 4470. DOI: https://doi.org/10.31979/etd.hdu7-gz7g

https://scholarworks.sjsu.edu/etd_theses/4470

This Thesis is brought to you for free and open access by the Master's Theses and Graduate Research at SJSU ScholarWorks. It has been accepted for inclusion in Master's Theses by an authorized administrator of SJSU ScholarWorks. For more information, please contact scholarworks@sjsu.edu. 


\title{
VULNERABILITY OF GROUNDWATER TO PERCHLOROETHYLENE CONTAMINATION FROM DRY CLEANERS IN THE NILES CONE GROUNDWATER BASIN, SOUTHERN ALAMEDA COUNTY, CALIFORNIA
}

\author{
A Thesis
}

Presented to

The Faculty of the Department of Geology

San José State University

In Partial Fulfillment

of the Requirements for the Degree

Master of Science

by

Anne C. Jurek

August 2014 
(C)2014

Anne C. Jurek

ALL RIGHTS RESERVED 
The Designated Thesis Committee Approves the Thesis Titled

\begin{abstract}
VULNERABILITY OF GROUNDWATER TO PERCHLOROETHYLENE CONTAMINATION FROM DRY CLEANERS IN THE NILES CONE GROUNDWATER BASIN, SOUTHERN ALAMEDA COUNTY, CALIFORNIA
\end{abstract}

\author{
by \\ Anne C. Jurek \\ APPROVED FOR THE DEPARTMENT OF GEOLOGY
}

SAN JOSÉ STATE UNIVERSITY

August 2014

Dr. June A. Oberdorfer

Dr. David W. Andersen

Ms. Mary Rose Cassa
Department of Geology

Department of Geology

San Francisco Bay Regional Water Quality Control Board 


\section{ABSTRACT \\ VULNERABILITY OF GROUNDWATER TO PERCHLOROETHYLENE CONTAMINATION FROM DRY CLEANERS IN THE NILES CONE GROUNDWATER BASIN, SOUTHERN ALAMEDA COUNTY, CALIFORNIA}

by Anne C. Jurek

Releases of perchloroethylene (PCE) from dry cleaners pose a threat to groundwater quality. An assessment was performed of the Niles Cone Groundwater Basin to determine its vulnerability to PCE contamination from both historic and more recently operating dry cleaners. Sensitivity assessments of the Basin's two subbasins were performed using a modification of the DRASTIC Index Method, whereby the hydrogeological variables of depth to water, aquifer media, vadose zone media, and soil drainage classification were represented by a range of sensitivity categories and ratings assigned to each range. A source assessment was performed by identifying the locations of historic and presently operating dry-cleaning plants and assigning a threat ranking to each based on the approximate years in which the four generations of dry-cleaning machinery were introduced. Using ArcGIS, the sensitivity assessments and the source assessment were mapped, and the source assessment was superimposed over the sensitivity maps to create vulnerability maps of the two subbasins. The most sensitive area of the Below Hayward Fault subbasin in the forebay area near the Hayward Fault is due to a higher proportion of coarse-grained aquifer and vadose zone media and a thinner to absent aquitard due to deposition from the Alameda Creek. The existence of dry cleaners of higher threat makes this an area that is vulnerable to PCE contamination. 


\section{ACKNOWLEDGEMENTS}

I would like to express my gratitude to my adviser Dr. June Oberdorfer for her intelligent guidance throughout the planning and writing of this thesis. I would also like to thank my thesis committee members, Dr. David Andersen and Mary Rose Cassa, for their thoughtful and helpful contributions. In addition, I would like to thank the following people: Dr. Richard Taketa, for patiently and thoroughly answering my questions related to ArcGIS; Douglas Young, Mikel Halliwell, and Tom Berkins at the Alameda County Water District and my fellow classmate, Ramon Cioco, for their assistance in providing data for my research; Timothy Swenson of the Fremont Museum of Local History, whose impressive knowledge of the history of the study area helped me with the identification of historic dry cleaners; and the staff at the UC Berkeley Earth Sciences and Map Library and the Fremont Main Library for their assistance in helping me locate street maps of the study area. I also wish to thank Ginny Smith for her assistance.

Finally, I want to pay tribute to my late parents, John and Ernestine Jurek, for encouraging me to pursue my interests and teaching me to persevere. And most of all, thank you Gary for your patience, love, and encouragement. 


\section{TABLE OF CONTENTS}

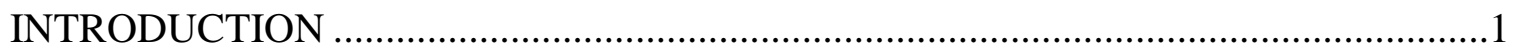

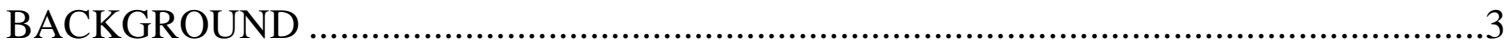

PCE and Threats Associated with Dry-Cleaning Activities ................................3

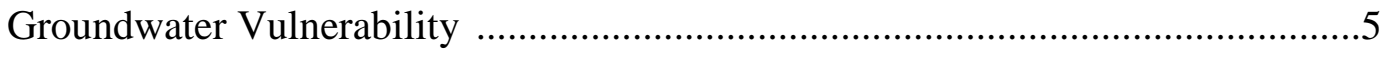

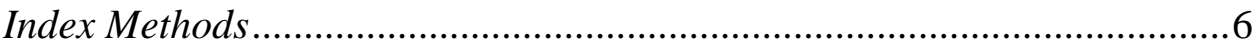

Statistical Methods ................................................................... 9

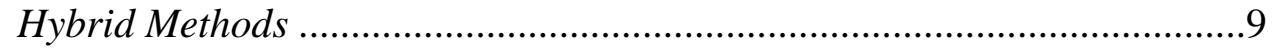

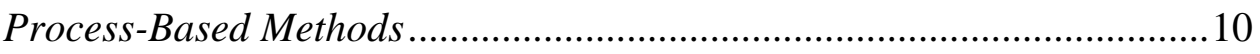

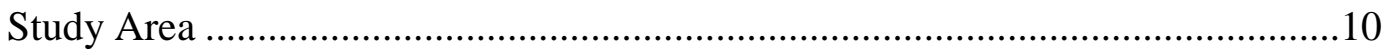

Basin Management by the Alameda County Water District...............................14

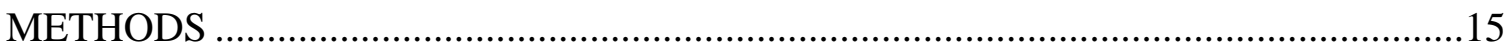

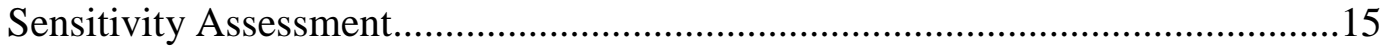

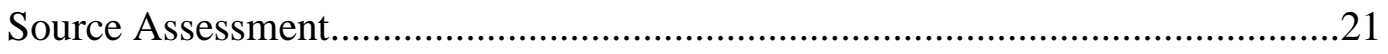

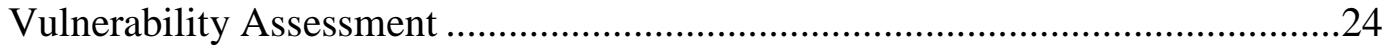

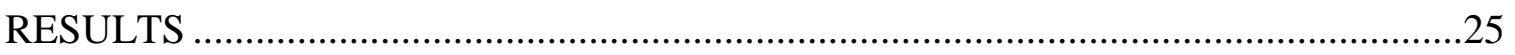

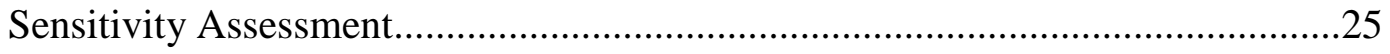

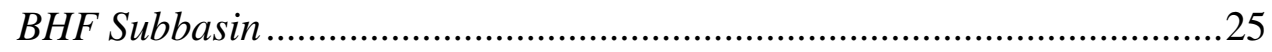

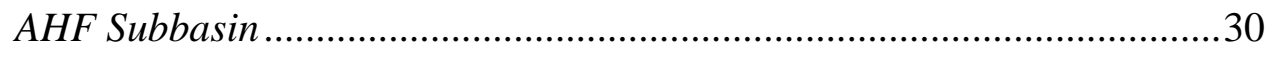

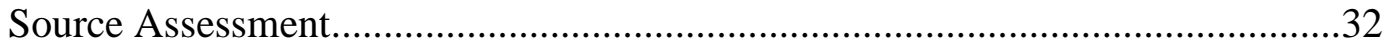

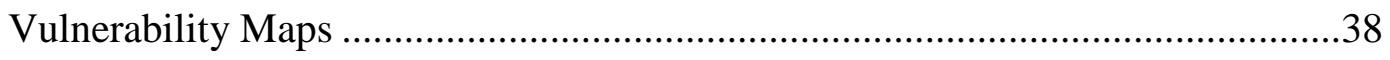




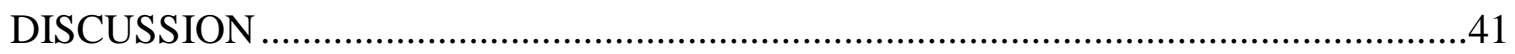

Sensitivity Assessments ...............................................................................4

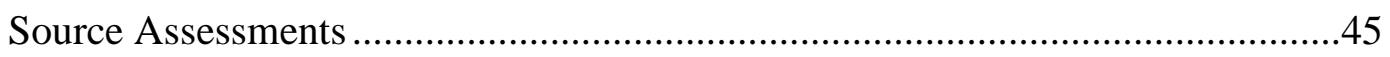

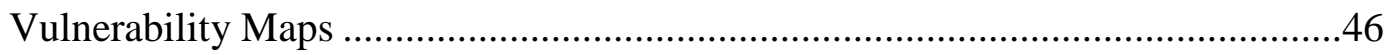

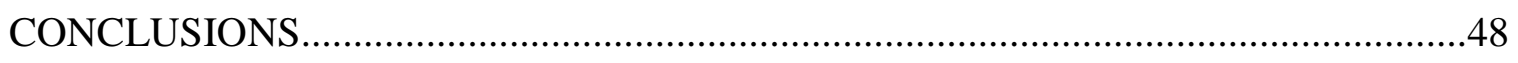

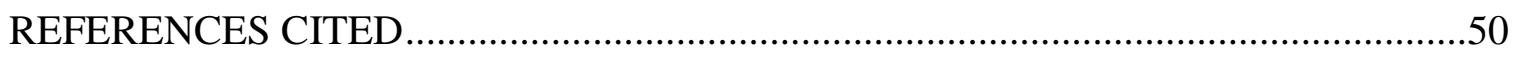

APPENDIX A. DRY-CLEANING PLANTS IN STUDY AREA ……………………....53

APPENDIX B. OLDER CLEANERS LOCATED AT STREET SEGMENT LEVEL....56

APPENDIX C. MAPS OF OLDER CLEANERS LOCATED AT STREET AND STREET SEGMENT LEVEL …………………………………..........57

APPENDIX D. DRY-CLEANING BUSINESSES FOR WHICH PLANTS STATUS

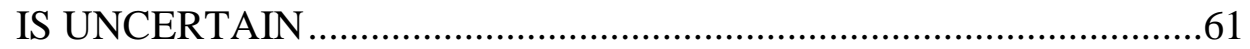

APPENDIX E. ENLARGED VULNERABILITY MAPS OF THE BHF SUBBASIN ...63 APPENDIX F. VULNERABILITY MAPS WITH CLEANERS FOR WHICH PLANT STATUS IN UNCERTAIN .66 


\section{LIST OF FIGURES}

Figure

1. Historical Trends in Dry-Cleaning Machinery and Ranges (Short and Long Bars) in Solvent Mileage Cited in Studies................................................................

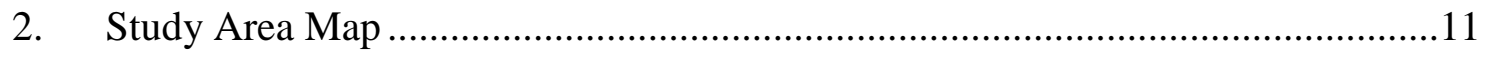

3. Niles Cone Groundwater Basin Cross-Section Schematic .................................13

4. Aquifer Media Sensitivity Ratings for the BHF Subbasin................................26

5. Vadose Zone Media Sensitivity Ratings for the BHF Subbasin.........................27

6. Depth to Water Sensitivity Ratings for the BHF Subbasin................................28

7. Soil Drainage Classification Ratings for the Niles Cone Groundwater Basin......29

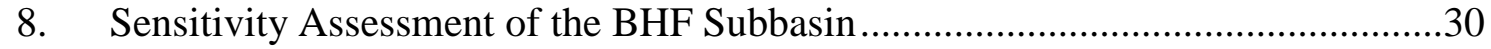

9. Depth to Water Sensitivity Ratings for the AHF Subbasin .................................32

10. Vadose Zone Media Sensitivity Ratings for the AHF Subbasin..........................33

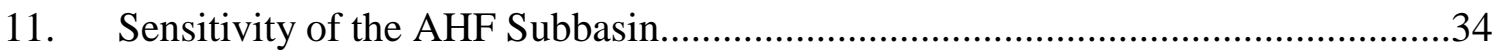

12. Threat Ranking of Dry-Cleaning Plants Based on Generation of Machinery .......36

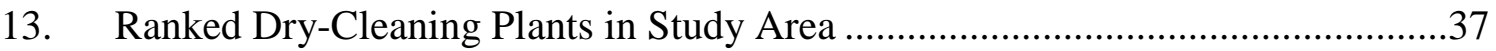

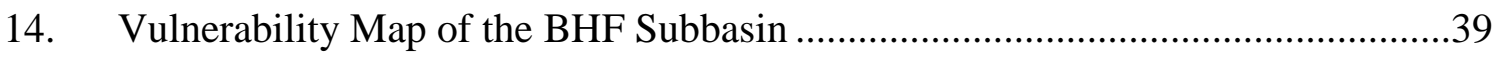

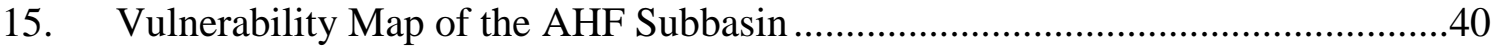




\section{LIST OF TABLES}

Table

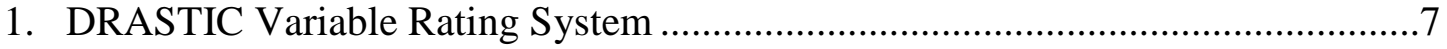

2. DRASTIC Weighting Factor System and Index Scoring ................................

3. Modified DRASTIC Variables, Data Sources and ArcGIS Analysis Performed ..16

4. Modified DRASTIC Variable Rating System .................................................19

5. Modified Weighting Factor System and Index Scoring .................................20 


\section{INTRODUCTION}

Groundwater is an important natural resource that provides $40 \%$ of the public drinking water supply, almost all of the rural population's drinking water, and about $60 \%$ of the water used in irrigation in the United States (Alley et al., 1999; Scanlon et al., 2012). In California, groundwater accounts for approximately $30 \%$ of the water used municipally and agriculturally, with that amount increasing to between 40 and $60 \%$ during droughts (CDWR, 2003). Therefore, protecting groundwater basins from contamination is important to ensure a reliable and safe water supply.

Spills and releases of solvent from dry cleaners pose a threat to water quality and human health. Groundwater basins in the San Francisco Bay Area are regulated by the San Francisco Bay Regional Water Quality Control Board (SFBRWQCB), which runs a Site Cleanup Program that oversees the investigation and cleanup of recent and historic dry-cleaning releases (Papler, 2011; SFBRWQCB, 2013). Of particular concern is perchloroethylene (PCE), also known as tetrachloroethylene, a toxic chlorinated solvent that is the most-used solvent for dry cleaning (Mohr, 2007; Papler, 2011). Concerns about PCE prompted the State Water Resources Control Board to mandate that the nine California Regional Water Quality Control Boards and the Department of Toxic Substance Control form a Dry Cleaner Workgroup. The Workgroup determined the need for studies to help locate past and present dry cleaners in the region with the greatest potential to contaminate (Papler, 2011). The Santa Clara Valley Water District (SCVWD) has already performed such a study on the Santa Clara groundwater basin (Mohr, 2007). Other groundwater basins in the southern portion of the San Francisco 
Bay Hydrologic Region include the Niles Cone Groundwater Basin that is managed by the Alameda County Water District (ACWD), the East Bay Plain that is overseen by the East Bay Municipal Utility District (EBMUD), and the San Mateo Plain that is overseen by the San Mateo County Environmental Health Service Division (CRWQCB, 2003; CDWR, 2003).

The purpose of this thesis research is to determine the vulnerability of groundwater in the Niles Cone Groundwater Basin in southern Alameda County, California to perchloroethylene contamination from past and present dry-cleaning operations that overlie the basin in Union City, Fremont, and Newark. A sensitivity assessment of the basin was performed, and a source assessment was performed by ranking dry cleaner sites based on their potential to contaminate groundwater with PCE. Using a Geographic Information System (GIS), a vulnerability map of the basin was generated in order to aid in the prioritization of PCE investigation and cleanup. 


\section{BACKGROUND}

\section{PCE and Threats Associated with Dry Cleaning Activities}

Perchloroethylene, also known as tetrachloroethylene, is classified as a probable human carcinogen. PCE is one of the four most commonly detected pollutants in California water-supply wells and exceeds the safe drinking water level in 429 watersupply wells in California (Mohr, 2007; Papler, 2011).

The dry-cleaning industry began using PCE in the late 1930s to early 1940s. By 1952, the-dry cleaning industry used $80 \%$ of the PCE produced. Over the following decades, PCE usage by the dry-cleaning industry decreased, so that by $1990,50 \%$ of the PCE manufactured was used by the dry-cleaning industry. However, 85 to $90 \%$ of dry cleaners in the US still use PCE (Mohr, 2007).

Dry-cleaning machinery has evolved over the years in solvent use efficiency and the potential for leakage. First-generation transfer machines that were introduced in the 1930s used at least five times as much solvent as is presently used by fourth-generation closed-loop dry-to-dry machines (Fig. 1). In addition, handling and disposal practices were not regulated until the mid-1980s (Mohr, 2007). Therefore, the year that a dry cleaner began operation is an important factor in the potential mass of PCE it could have released. The duration of time that a dry cleaner operated is also an important factor, as the potential mass of PCE released increased with a longer duration of an operation (Mohr, 2007). 


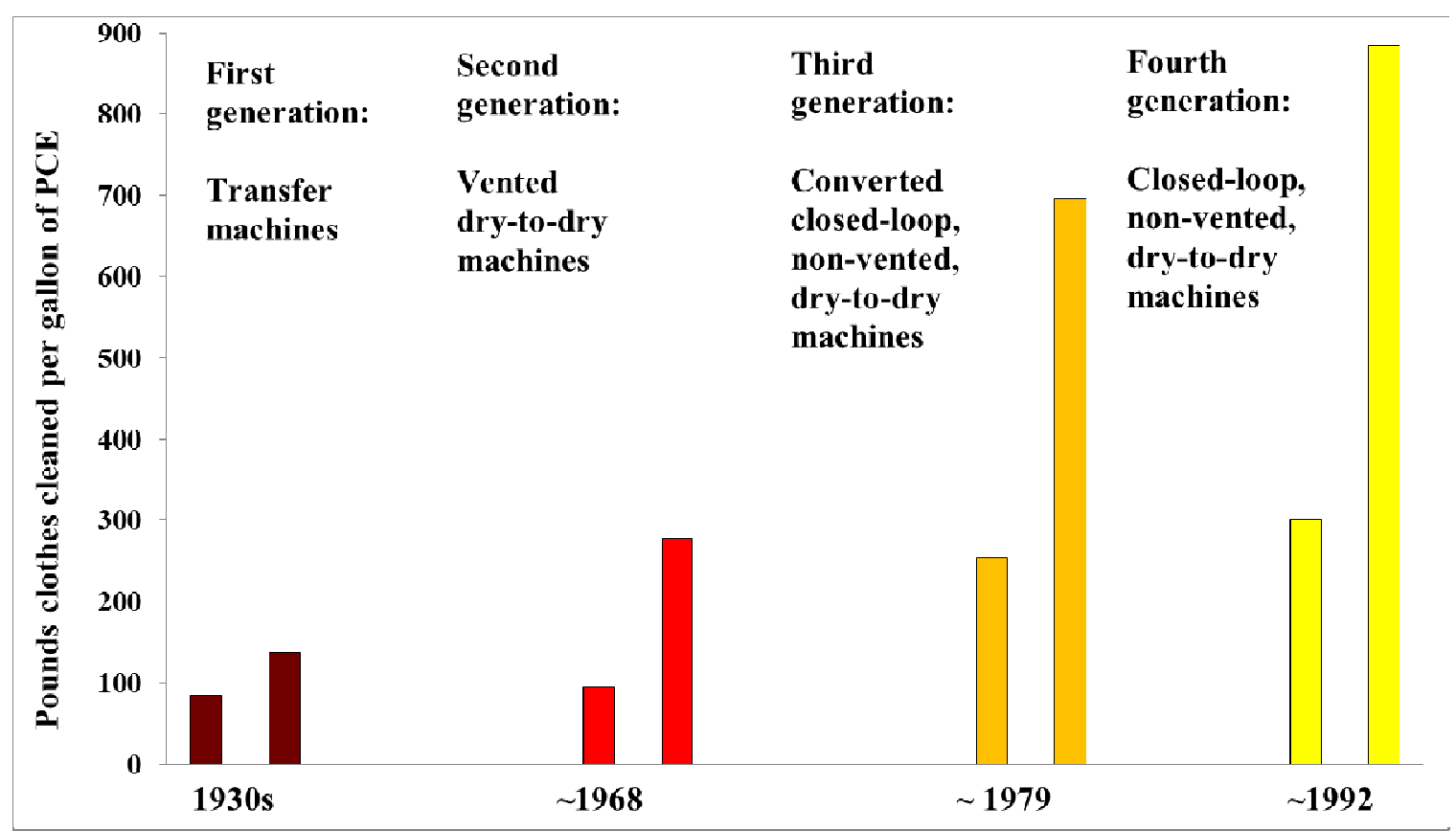

Figure 1. Historical trends in dry-cleaning machinery and ranges (short and long bars) in solvent mileage cited in studies (based on DHHS, 1997, Jacobs Engineering, 2004; Mohr, 2007).

PCE, a dense nonaqueous phase liquid (DNAPL), occurs as a residual fluid within the vadose zone and aquifer media pores. In addition, it volatilizes and spreads in the vadose zone as a vapor phase. Within the aquifer, it ponds on low permeability layers and creates a plume when dissolved in flowing groundwater (Domenico and Schwartz, 1998).

The pathway that PCE takes to impact soil or groundwater depends on the release mechanism, the release location, and the mass released. Different release mechanisms can result in different masses released. Release mechanisms of PCE at dry-cleaning sites include the following: equipment failure, solvent transfer and delivery, discharge from 
waste water separators to leaking sewer lines and septic systems, and storage of solvent and used cartridge filters (Mohr, 2007). The soil beneath the floor slab near dry-cleaning machines and distillation units is a common release location, as this is associated with releases from equipment failures. PCE is also often released as liquid or vapor through breaks at low spots in sewer lines where contaminated liquid and sludge have settled (Mohr, 2007).

\section{Groundwater Vulnerability}

Concerns about groundwater contamination and drinking water safety have led to the development and increased use of groundwater vulnerability studies to aid in policy development and resource management (NRC, 1993). Groundwater vulnerability is defined by the United States Environmental Protection Agency (USEPA) as "the relative ease with which a contaminant... applied on or near the land surface can migrate to the aquifer of interest under a given set of agronomic management practices, [contaminant] characteristics and hydrogeologic sensitivity conditions" (USEPA, 1993). The two components of groundwater vulnerability are groundwater sensitivity and potentially contaminating activities (NRC, 1993; Todd Engineers and Kennedy/Jenks Consultants, 2010). Groundwater sensitivity is based on the intrinsic characteristics of the aquifer, such as hydraulic conductivity, porosity, hydraulic gradient, and the overlying unsaturated materials, but can also include stresses to the groundwater system such as pumping and recharge (NRC, 1993; Focazio et al., 2002; Todd Engineers and 
Kennedy/Jenks Consultants, 2010). Potentially contaminating activities (PCAs) usually refer to current or past human activities at the ground surface that could potentially contaminate groundwater (Todd Engineers and Kennedy/Jenks Consultants, 2010).

\section{Index Methods}

One methodology used in groundwater sensitivity and vulnerability studies is the index method. Index methods assign numerical scores or ratings to a pre-defined list of hydrogeologic parameters to develop a range of sensitivity categories (NRC, 1993; Focazio et al., 2002; Todd Engineers and Kennedy/Jenks Consultants, 2010). The most commonly used index method for sensitivity analysis is DRASTIC. Developed by the USEPA, DRASTIC is an acronym for the seven hydrogeologic variables of: Depth to Water, Net Recharge, Aquifer Media, Soil Media, Topography, Impact of Vadose Zone, and Aquifer Hydraulic Conductivity (Aller et al., 1987; Focazio et al., 2002; Todd Engineers and Kennedy/Jenks Consultants, 2010). Each of the seven variables is represented by a range of categories, and predetermined numerical rating values are assigned within each range based on its contribution to basin sensitivity or contamination potential (Table 1). Each of the variables is then multiplied by a weighting factor (Table 2), and a final index score is calculated (Aller et al., 1987; Todd Engineers and Kennedy/Jenks Consultants, 2010).

The SCVWD study of the potential of dry cleaners to contaminate the basin used an index methodology. In addition to using the DRASTIC index to determine groundwater sensitivity, the study also took into account the locations of the dry cleaners 
Table 1. DRASTIC variable rating system (modified from Aller et al., 1987).

\begin{tabular}{|lr|}
\hline \multicolumn{2}{|c|}{ Depth to Water } \\
\hline Feet bgs & Rating \\
$0-5$ & 10 \\
$5-15$ & 9 \\
$15-30$ & 7 \\
$30-50$ & 5 \\
$50-75$ & 3 \\
$75-100$ & 2 \\
$100-199$ & 1 \\
\hline
\end{tabular}

\begin{tabular}{|lr|}
\hline \multicolumn{2}{|c|}{ Net Recharge } \\
\hline in/yr & Rating \\
& \\
$0-2$ & 1 \\
$2-4$ & 3 \\
$4-7$ & 3 \\
$7-10$ & 8 \\
$10+$ & 9 \\
\hline
\end{tabular}

\begin{tabular}{|lr|}
\hline \multicolumn{2}{|c|}{ Aquifer Media } \\
\hline \multicolumn{2}{|c|}{ Type } \\
Massive Shale & Rating \\
Metamorphic/Igneous & $1-3(2)$ \\
Weathered Metamorphic/ & $2-5(3)$ \\
$\quad$ Igneous & $3-5(4)$ \\
Glacial Till & $4-6(5)$ \\
Bedded Sandstone, Limestone and \\
$\quad$ Shale Sequences & $5-9(6)$ \\
Massive Sandstone or & $4-9(6)$ \\
$\quad$ Limestone & $4-9(8)$ \\
Sand and Gravel & $2-10(9)$ \\
Basalt & $9-10(10)$ \\
Karst Limestone
\end{tabular}

\begin{tabular}{|lr|}
\hline \multicolumn{2}{|c|}{ Soil Media } \\
\hline Type Rating \\
Thin or Absent & 10 \\
Gravel & 10 \\
Sand Peat Aggregated Clay & 9 \\
Shrinking and/or & 8 \\
Sandy Loam & 7 \\
Loam Silty Loam & 6 \\
Clay Loam & 5 \\
Muck Non-shrinking/ & 4 \\
Non-aggregated Clay & 3 \\
\end{tabular}

\begin{tabular}{|lr|}
\hline \multicolumn{2}{|c|}{ Topography } \\
\hline Percent slope & Rating \\
& \\
$0-2$ & 10 \\
$2-6$ & 9 \\
$6-12$ & 5 \\
$12-18$ & 3 \\
$18+$ & 1 \\
\hline
\end{tabular}

\begin{tabular}{|lr|}
\hline \multicolumn{2}{|c|}{ Hydraulic Conductivity } \\
\hline $\mathrm{gpd} / \mathrm{ft}^{2}$ & Rating \\
$1-100$ & 1 \\
$100-300$ & 2 \\
$300-700$ & 4 \\
$700-1,000$ & 6 \\
$1,000-2,000$ & 8 \\
$2,000+$ & 10 \\
\hline
\end{tabular}

\begin{tabular}{|lr|}
\hline \multicolumn{2}{|c|}{ Impact of the Vadose Zone } \\
\hline Type & Rating \\
& \\
Confining Layer & $1(1)$ \\
Silt/Clay & $2-6(3)$ \\
Shale & $2-5(3)$ \\
Limestone & $2-7(6)$ \\
Sandstone & $4-8(6)$ \\
Bedded Limestone, & \\
$\quad$ Sandstone,Shale & $4-8(6)$ \\
Sand and Gravel with & \\
$\quad$ Significant Clay & $4-8(6)$ \\
Metamorphic/Igneous & $2-8(4)$ \\
Sand and Gravel & $6-9(8)$ \\
Basalt & $2-10(9)$ \\
Karst Limestone & $8-10(10)$ \\
\hline
\end{tabular}

bgs $=$ below ground surface

gpd $=$ gallons per day

in $=$ inches

yr= year

Ratings for Aquifer Media and Impact of Vadose Zone are provided as a range; any value within the range can be used; values shown in parentheses are typical values. 
with respect to groundwater flow and the nearest supply wells. It also used a well vulnerability ranking based on features of well construction and operation. It combined these parameters with the relative mass of PCE released by dry cleaners as the potential contaminant of concern to produce a vulnerability map (Mohr, 2007).

Table 2. DRASTIC weighting factor system and index scoring (modified from Aller et al., 1987).

\begin{tabular}{|c|c|}
\hline Hydrogeologic Variable & Weighting Factor \\
\hline Depth to Water (D) & $5(\mathrm{a})$ \\
\hline Net Recharge (R) & $4(\mathrm{~b})$ \\
\hline Aquifer Media (A) & $3(\mathrm{c})$ \\
\hline Soil Media (S) & $2(\mathrm{~d})$ \\
\hline Topography (T) & $1(\mathrm{e})$ \\
\hline Impact of Vadose Zone (I) & $5(\mathrm{f})$ \\
\hline Hydraulic Conductivity (C) & $3(\mathrm{~g})$ \\
\hline
\end{tabular}

DRASTIC Index Score $=\mathrm{aD}+\mathrm{bR}+\mathrm{cA}+\mathrm{dS}+\mathrm{eT}+\mathrm{fI}+\mathrm{gC}$

In order to determine the relative mass of PCE released by dry cleaners, an AgeDuration threat ranking was developed based on the year that a dry cleaning operation began, or age, and the number of years of operation, or duration. The rankings were derived based on assumed solvent mileage for each generation of machinery and assumed leakage rates that represented the total solvent mileage over the duration of a dry cleaning operation (Mohr, 2007).

\section{Statistical Methods}

Statistical methodology involves the simultaneous analysis of more than one variable when correlating physical parameters to water quality data in order to predict the 
probability of contamination (NRC, 1993; Todd Engineers and Kennedy/Jenks Consultants, 2010). A common statistical test used in groundwater sensitivity and vulnerability assessments is logistical regression, which looks at the probability of groundwater exceeding a certain contaminant concentration level at a specific location. Water quality data, similar to groundwater sensitivity, may be influenced not only by intrinsic hydrogeologic parameters but also by anthropogenic stresses to the groundwater system. All of these potential explanatory variables can be analyzed for significance, and those variables that do not explain variations in observed groundwater quality can be eliminated (Todd Engineers and Kennedy/Jenks Consultants, 2010).

\section{Hybrid Methods}

Hybrid methods combine components of index and statistical methods. They can use predefined scoring systems, such as DRASTIC, or can use project-specific factors or subjective categorization. In addition, they can also use hypothesis testing to select or calibrate ratings or weights for variables used in index methods to predict the probability of contamination (NRC, 1993; Focazio et al., 2002; Antonakos and Lamrakis, 2007; Todd Engineers and Kennedy/Jenks Consultants, 2010). The use of hypothesis testing in hybrid methods makes them a more reliable predictor of groundwater contamination compared to index methods (Rupert, 2001; Panagopoulos et al., 2006). 


\section{Process-Based Methods}

In contrast to other methods, process-based methods are used to predict contaminant transport in both space and time by mathematically modeling subsurface contaminant behavior using first-order deterministic equations and physically based techniques. The intrinsic sensitivity of an aquifer may be determined by analyzing the source and movement of groundwater by using numerical groundwater flow modeling and age-dating of water. Groundwater vulnerability may be estimated by focusing on the source and movement of the contaminant by using solute transport modeling or geochemical modeling (NRC, 1993; Todd Engineers and Kennedy/Jenks Consultants, 2010).

\section{Study Area}

The Niles Cone Groundwater Basin is located in the southern portion of Alameda County, California. It is bounded on the south by the Alameda-Santa Clara County boundary, on the north by the southern portion of the City of Hayward, on the east by the Diablo Range, and on the west by the San Francisco Bay (Fig. 2). The principal stream in the basin is Alameda Creek, which flows westward from the Diablo Range to the San Francisco Bay. The basin has a surface area of approximately $267 \mathrm{~km}^{2}\left(103 \mathrm{mi}^{2}\right)$ (CDWR, 2003). It is comprised of Quaternary deposits of alluvial fan material of unconsolidated gravel, sand, silt and clay deposited by Alameda Creek as it exits 


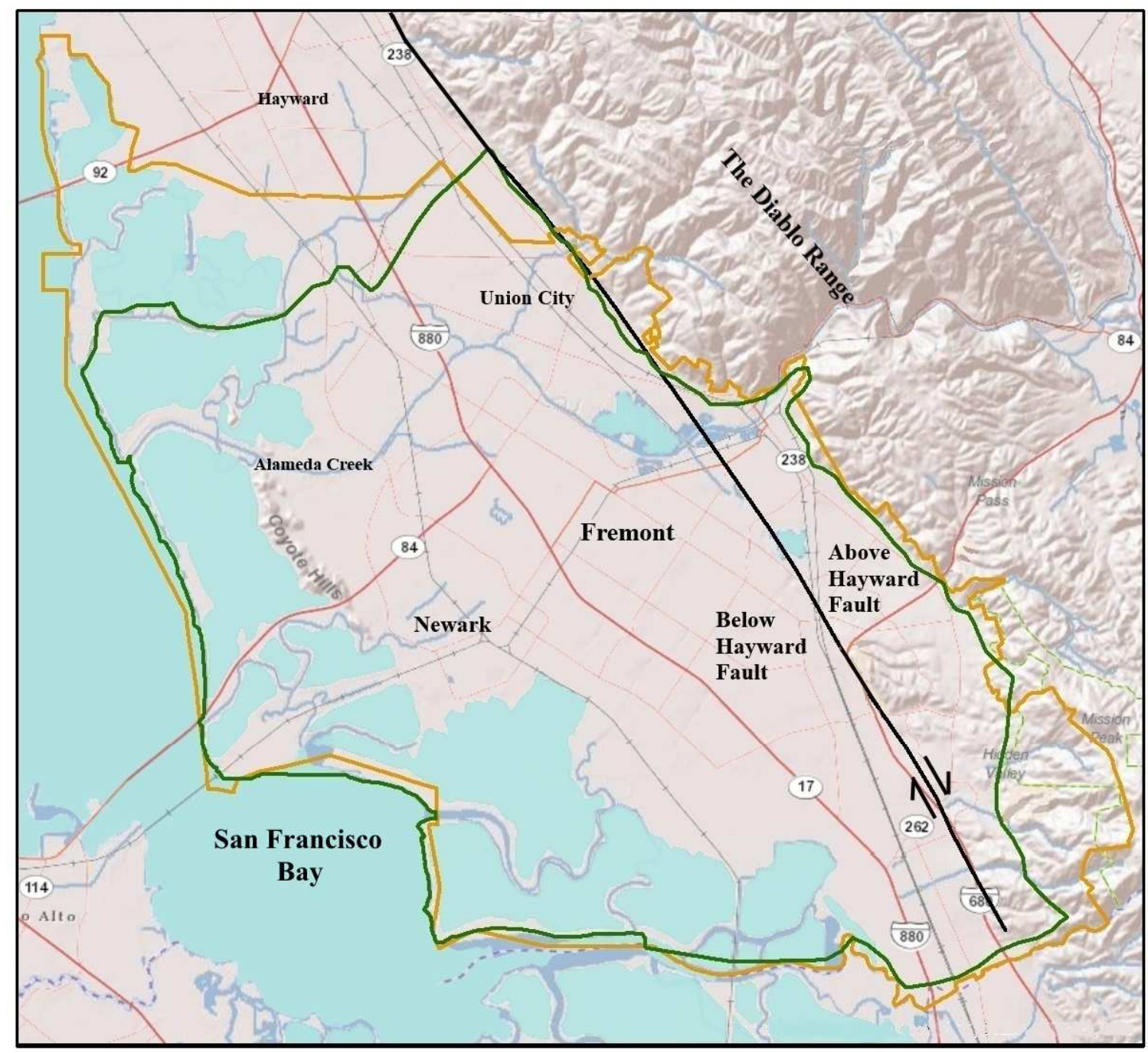

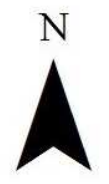

$10,000 \quad 5,000 \quad 0$

\section{Legend}

Niles Cone Groundwater Basin boundary

Alameda County Water District boundary

Hayward Fault

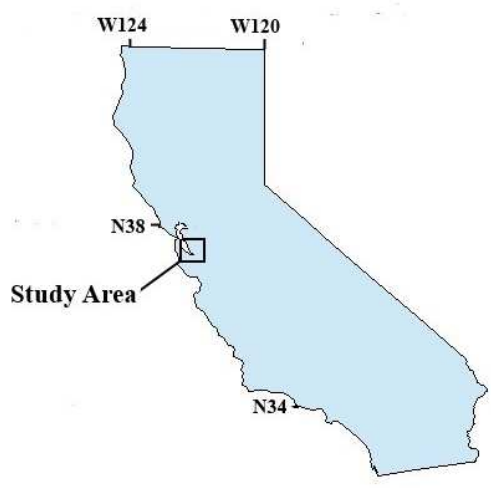

Figure 2. Study area map (modified from CDWR, 2013; ESRI 2013a, 2013b; U.S. Census Bureau, 2013). 
the Diablo Range. The basin contains thick aquifers interbedded with aquitards due to the effects of the glacial and interglacial cycles in the San Francisco Bay region (CDWR, 2003; CRWQCB, 2003).

The Hayward fault (HF), part of the San Andreas fault system, trends in a general northwest-southeast direction cutting across the Niles Cone alluvial fan. It divides the basin into two subbasins, the Below Hayward Fault (BHF) on its west side and the Above Hayward Fault (AHF) on its east side (Fig. 3). The AHF subbasin consists of a forebay region of essentially one coarse sand and gravel aquifer that is mostly unconfined (CDWR, 2003; CRWQCB, 2003). The BHF subbasin is comprised, from shallowest to deepest, of the following: a thin upper aquitard, and a localized Shallow aquifer within the top-lying Newark Aquitard. The shallow aquifer interconnects in a few places with the underlying Newark Aquifer (Ciocco, 2012). Within the BHF, the Newark Aquitard is absent in the forebay area near the intersection of the Alameda Creek with the HF (CRWQCB, 2003; ACWD, 2010).

The Newark Aquitard is underlain by three major westward dipping aquifers, in order of increasing depth, the Newark, Centerville-Fremont, and Deep Aquifers, which are separated by extensive clay aquitards (Fig. 3) (CRWQCB, 2003; ACWD, 2010). The Newark Aquifer is the shallowest water-supply aquifer, and therefore is the first watersupply aquifer in the basin likely to be impacted by surface contamination. For this reason, it is the main aquifer of concern in this project. It is an extensive permeable gravel and sand layer that underlies most of the Niles Cone fan, and is the uppermost aquifer west of the fault. It lies between 12 and $43 \mathrm{~m}$ (40 and $140 \mathrm{ft}$ ) below ground 


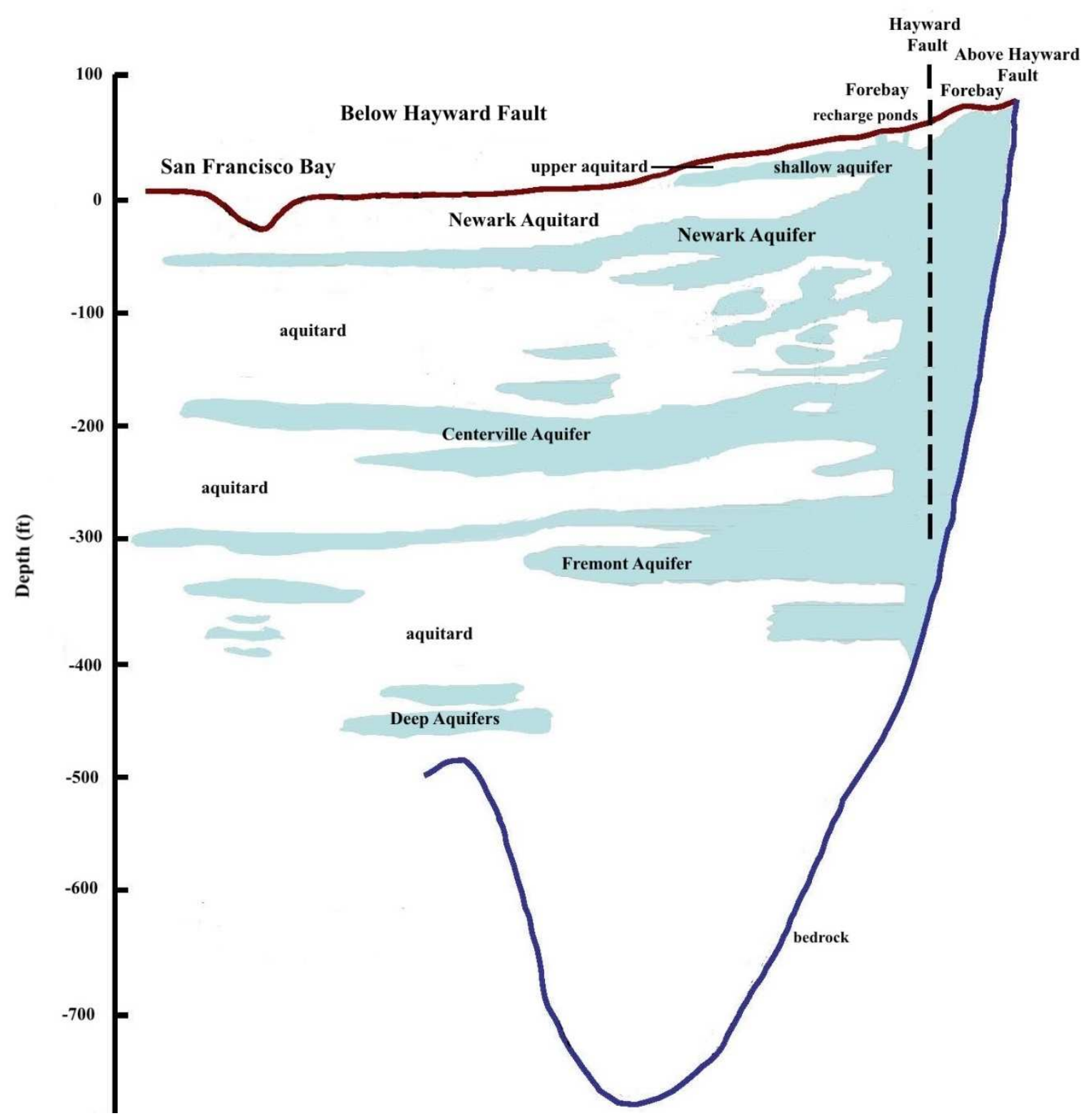

Figure 3. Niles Cone Groundwater Basin cross-section schematic (modified from ACWD, 2012).

surface (bgs). It is confined except in the vicinity of the fault, where the overlying aquitard is absent (Moran et al., 2002; CDWR, 2003; CRWQCB, 2003; ACWD, 2010). 


\section{Basin Management by the Alameda County Water District}

Groundwater from the Niles Cone Groundwater Basin provides about $35 \%$ of the water supply for the ACWD in general and during dry years it can contribute over $60 \%$ of the supply, with imported water accounting for the remainder (ACWD, 2010). The District replenishes the basin primarily with runoff from the Alameda Creek watershed (ACWD, 2010). The runoff is captured by inflatable rubber dams at the Alameda Flood Control Channel and diverted to percolation ponds at the District's recharge facility. This facility is located in the forebay near the Hayward fault where the overlying aquitard is absent, allowing for direct recharge into the basin. To a lesser extent, imported water is diverted to the ponds, contributing to basin recharge (James M. Montgomery, Inc., 1991; ACWD, 2010, 2012).

Excessive groundwater pumping from the basin until the early 1960s resulted in salt water intrusion from the San Francisco Bay into the western portion of the BHF aquifer system. Subsequently, imported water from the State Water Project (SWP) was used to raise water table levels and restore the hydraulic gradient direction toward the bay. The Aquifer Reclamation Program (ACP), which was established by the District in 1974, pumps out brackish water still remaining in the aquifers to improve groundwater quality, increase basin storage, and prevent further salt water intrusion. Although some of the saline water is pumped back to the Bay, most is now treated via desalination and used as drinking water (ACWD, 2010, 2012). 


\section{METHODS}

\section{Sensitivity Assessment}

A modified version of the DRASTIC index method (Aller et al., 1987) was used to perform the sensitivity assessment of the Niles Cone Groundwater Basin. Due to differences in the available data for the AHF and BHF subbasins, the general impermeability of the Hayward Fault that divides them, and their different aquifer systems, separate sensitivity assessments were performed on each subbasin. The aquifer of concern in the AHF subbasin is the mostly unconfined coarse-grained aquifer that comprises it. The main aquifer of concern in the BHF subbasin is the mostly confined Newark Aquifer, as it is the subbasin's shallowest water-supply aquifer and therefore the most likely to be contaminated. Table 3 provides a summary of the variables used for each subbasin and their data sources. Using ESRI ArcGIS 10 software, a GIS layer was made for the each of the variables. The ArcGIS analysis that was performed on each variable is summarized in Table 3.

Depth to water (DTW) was used as a variable in the sensitivity assessments of both subbasins due to the generally uniform distribution of the stratigraphic and lithologic borehole records and DTW well data in both areas, with the exception of the southernmost portion of the AHF subbasin. DTW is an important variable in determining the extent to which attenuation of contamination is likely to occur due to the thickness of material the contaminant travels through in order to reach the uppermost aquifer. In 
Table 3. Modified DRASTIC variables, data sources and ArcGIS analysis performed.

\begin{tabular}{|c|c|c|c|}
\hline & Variable & Data Source & ArcGIS Analysis \\
\hline \multicolumn{4}{|c|}{ Depth to Water } \\
\hline 1) & $\begin{array}{l}\text { Depth to top of } \\
\text { aquifer for confined } \\
\text { Newark Aquifer }\end{array}$ & $\begin{array}{l}\text { One hundred thirteen borehole logs from the } \\
\text { ACWD borehole database. Six borehole logs } \\
\text { from the ACWD Inland Salt Intrusion } \\
\text { Monitoring Well Project (ACWD, 2010a). } \\
\text { Based on hydrostratigraphic interpretation by } \\
\text { Cioco (2012). }\end{array}$ & $\begin{array}{l}\text { Excel spreadsheet of values } \\
\text { for DTW converted to point } \\
\text { feature class; points } \\
\text { interpolated to raster GRID } \\
\text { in Spatial Analyst using } \\
\text { Inverse Distance Weighting } \\
\text { (IDW). }\end{array}$ \\
\hline 2) & $\begin{array}{l}\text { Depth to water table } \\
\text { for unconfined areas } \\
\text { of Newark Aquifer } \\
\text { and the unconfined } \\
\text { aquifer in the AHF } \\
\text { subbasin }\end{array}$ & $\begin{array}{l}\text { ACWD Groundwater Monitoring Report } 2011 \\
\text { (ACWD, 2010a). State Water Resources } \\
\text { Control Board GeoTracker }\end{array}$ & \\
\hline \multicolumn{2}{|c|}{$\begin{array}{l}\text { Aquifer Media } \\
\text { Only included in the sensitivity } \\
\text { assessment of the BHF } \\
\text { subbasin }\end{array}$} & $\begin{array}{l}\text { One hundred thirteen borehole logs from the } \\
\text { ACWD borehole database. Six borehole logs } \\
\text { from the ACWD Inland Salt Intrusion } \\
\text { Monitoring Well Project (ACWD, 2010a). } \\
\text { Based on lithologic description of } \\
\text { hydrostratigraphic unit interpretation by Cioco } \\
\text { (2012). }\end{array}$ & $\begin{array}{l}\text { Excel spreadsheet of values } \\
\text { of weighted sum average of } \\
\text { aquifer material converted } \\
\text { to point feature class; } \\
\text { points interpolated to raster } \\
\text { GRID using IDW. }\end{array}$ \\
\hline \multicolumn{2}{|c|}{ Soil Media } & $\begin{array}{l}\text { Soil Survey Geographic (SSURGO) Database } \\
\text { from the National Resources Conservation } \\
\text { Service (NRCS) of US Department of } \\
\text { Agriculture (USDA) in shapefile. }\end{array}$ & $\begin{array}{l}\text { Shapefile of drainage } \\
\text { classifications of major soil } \\
\text { series of map units } \\
\text { converted to raster GRID. }\end{array}$ \\
\hline \multicolumn{4}{|c|}{ Vadose Zone Media } \\
\hline 1) & $\begin{array}{l}\text { Both unsaturated and } \\
\text { saturated media in } \\
\text { confining unit over } \\
\text { the Newark Aquifer }\end{array}$ & $\begin{array}{l}\text { One hundred thirteen borehole logs from the } \\
\text { ACWD borehole database. Six borehole logs } \\
\text { from the ACWD Inland Salt Intrusion } \\
\text { Monitoring Well Project (ACWD, 2010a). } \\
\text { Based on lithologic descriptions of the } \\
\text { hydrostratigraphic interpretation of upper } \\
\text { aquitard, shallow aquifer, and the Newark } \\
\text { Aquitard by Cioco (2012). }\end{array}$ & $\begin{array}{l}\text { Excel spreadsheet of values } \\
\text { of weighted sum average of } \\
\text { vadose zone material } \\
\text { converted to point feature } \\
\text { class; points interpolated to } \\
\text { raster GRID using IDW. }\end{array}$ \\
\hline 2) & $\begin{array}{l}\text { Unsaturated aquifer } \\
\text { media above the } \\
\text { water table in } \\
\text { unconfined areas of } \\
\text { the AHF and BHF } \\
\text { subbasins. }\end{array}$ & $\begin{array}{l}\text { For the BHF subbasin, lithologic descriptions } \\
\text { for Newark Aquifer from ACWD borehole } \\
\text { logs. DTW from ACWD Groundwater } \\
\text { Monitoring Report } 2011 \text { (ACWD, 2010a). } \\
\text { For the AHF subbasin, lithologic descriptions } \\
\text { for the unconfined aquifer from five ACWD } \\
\text { borehole logs and six well borehole logs from } \\
\text { State Water Resources } \\
\text { Control Board GeoTracker. DTW from the } \\
\text { ACWD Groundwater Monitoring Report } 2011 \\
\text { and Geotracker. }\end{array}$ & \\
\hline
\end{tabular}


accordance with the original DRASTIC method, depth to the water table was used for the unconfined areas of both subbasins, and depth to the top of the aquifer was used for the confined areas of the BHF subbasin (Table 3).

Soil media was included as a variable in the sensitivity assessments of both subbasins due to the availability of data. It is considered an important parameter in the DRASTIC method due to the influence of soil texture on the ease of infiltration of a contaminant from the land surface into the vadose zone, as well as on the extent to which the contaminant is attenuated.

The variables of aquifer and vadose zone media were used in the sensitivity assessment of the BHF subbasin because the boreholes with stratigraphic and lithologic records from the ACWD were adequately distributed throughout the subbasin. Both variables in the DRASTIC method take into consideration the attenuation of contamination based on the permeability of the media, with the aquifer media more specifically representing the ability of a contaminant to spread. In accordance with the original DRASTIC method, both the unsaturated and saturated sediments in the confining layer over the Newark Aquifer were considered as the vadose zone.

Borehole records from the ACWD for the AHF subbasin were only available for a restricted area near Alameda Creek. Additional borehole logs for this area were available from GeoTracker, the State Water Resources Control Board's data management system. In both sets of records, data were only available in the AHF subbasin for the vadose zone media and not the aquifer media due to the shallowness of the borings. Therefore, the variable of aquifer media was not included in the sensitivity assessment of AHF subbasin. 
In accordance with the DRASTIC method, the unsaturated sediment above the water table in the unconfined AHF subbasin was considered the vadose zone.

Data for hydraulic conductivity were available from the ACWD Integrated Groundwater-Surface Water Model (IGSM) (James M Montgomery Consulting Engineers, Inc., 1991). In the model, hydraulic conductivity was based on data from investigations performed by the Department of Water Resources and then adjusted through calibration by the percentage of gravel and sand from well logs. Because the representation of hydraulic conductivity in the model was similar to the thicknessweighted average of lithology performed on the aquifer media, hydraulic conductivity was not included as a variable in the sensitivity assessment. Recharge data were also available from the ACWD IGSM. However, only one recharge value was assigned to each subbasin. Due to the lack of variation in recharge data within each subbassin, it was not included as a variable. Due to the lack of variation in the slope of the land surface in the study area, with the exception of the most southeast portion of the study area where no dry cleaners were located, topography was not included as a variable.

The modified index method used in the sensitivity assessment is shown in Table 4. The original DRASTIC categories, ranges and ratings were retained for depth to water. The aquifer media in the BHF subbasin and vadose zone media in both subbasins were recategorized due to their smaller range of media types compared to those used as categories in the original DRASTIC method. In addition, to better delineate the variation in the sensitivity of the vadose zone, the vadose zone media for the confined aquifer were categorized and rated, which contrasts to the original DRASTIC method of rating the 
confining layer of a confined aquifer as 1 regardless of the type of material.

Table 4. Modified DRASTIC variable rating system

\begin{tabular}{|lc|}
\hline \multicolumn{2}{|c|}{ Depth to Water } \\
\hline Feet bgs & Rating \\
& \\
$0-5$ & 10 \\
$5-15$ & 9 \\
$15-30$ & 7 \\
$30-50$ & 5 \\
$50-75$ & 3 \\
$75-100$ & 2 \\
$100-199$ & 1 \\
\hline
\end{tabular}

\begin{tabular}{|lccc|}
\hline \multicolumn{3}{c|}{ Aquifer Media } \\
\hline $\begin{array}{l}\text { Grain size } \\
\text { Rating }\end{array}$ & $\begin{array}{c}\text { Thickness- } \\
\text { weighted Average }\end{array}$ & $\begin{array}{c}\text { Media } \\
\text { Rating }\end{array}$ \\
gravel 10 & $>9-10$ & 10 \\
sand 6 & $>7-9$ & 7 \\
silt & 3 & $>5-7$ & 4 \\
clay 1 & $>4-5$ & 2 \\
& & & \\
\hline
\end{tabular}

\begin{tabular}{|lc|}
\hline \multicolumn{2}{|c|}{ Soil Media } \\
\hline Drainage Classification & Rating \\
& \\
Excessively drained & 10 \\
Somewhat excessively drained & 9 \\
Well drained & 7 \\
Moderately well drained & 5 \\
Somewhat poorly drained & 3 \\
Poorly drained & 2 \\
Very poorly drained & 1 \\
\hline
\end{tabular}

\begin{tabular}{|lccc|}
\hline \multicolumn{3}{|c|}{ Vadose Zone Media } \\
\hline Grain size & $\begin{array}{c}\text { Thickness- } \\
\text { weighted Average }\end{array}$ & $\begin{array}{c}\text { Media } \\
\text { Rating }\end{array}$ \\
Rating & & \\
gravel & 10 & $>7-10$ & 10 \\
sand & 6 & $>4-7$ & 7 \\
silt & 3 & $>2-4$ & 4 \\
clay & 1 & $>1-2$ & 2 \\
& & & \\
\hline
\end{tabular}

The material of the Newark Aquifer is mostly sand and gravel with occasional clay and silt stringers, and the vadose zone material is mostly clay with some areas of the Newark Aquitard interbedded with sand lenses of the shallow aquifer. In order to better represent the permeability and range of contamination potential, a thickness-weighted average of the grain size of the aquifer and vadose zone media was performed on each borehole log. Gravel, sand, silt and clay were respectively assigned ratings of 10, 6, 3, and 1, with the coarser material assigned the higher sensitivity value. The sum of the weighted thickness of each lithological type was divided by the total thickness of the 
aquifer to obtain a weighted average, which was then rounded to the nearest whole number. Category ranges were created based on the thickness-weighted average, and sensitivity ratings were assigned to each range (Table 4).

Data for soil media variable were based on map units and their major soil series from the Soil Survey Geographic (SSURGO) database. The soil texture descriptions in many of the soil series were not similar to the DRASTIC soil media texture categories (Table 1). Therefore, modifications were also made to the original DRASTIC method for this variable. Because an important quality of soil is its permeability and the ease with which contamination is transmitted through it, drainage classifications of the major soil series were used as categories. The ArcGIS layers created for each variable were reclassified in ArcGIS using the Spatial Analyst tool according to the numerical ratings assigned to the category ranges (Table 4). Using the Weighted Sum Overlay tool in Spatial Analyst, a sensitivity map was created for each subbasin based on a modified index score that used the original DRASTIC method weighting factors for each variable (Table 5).

Table 5. Modified weighting factor system and index scoring.

\begin{tabular}{|l|l|}
\hline \multicolumn{1}{|c|}{ Hydrogeologic Variable } & \multicolumn{1}{c|}{ Weighting Factor } \\
\hline Depth to Water (D) & 5 (a) \\
\hline Aquifer Media (A) & $3(\mathrm{~b})$ \\
\hline Soil Media (S) & 2 (c) \\
\hline Vadose Zone (V) & 5 (d) \\
\hline
\end{tabular}

Modified Index Score for the AHF subbasin $=\mathrm{aD}+\mathrm{cS}+\mathrm{dV}$ Modified Index Score for BHF subbasin $=\mathrm{aD}+\mathrm{bA}+\mathrm{cS}+\mathrm{dV}$ 


\section{Source Assessment}

The first part of the source assessment was to identify historic and present-day dry cleaners that used or use PCE on-site in the cities of Fremont, Newark, and Union City. An attempt was made to identify businesses as far back as the late 1930s to early 1940s, as this was when the dry cleaning industry began using PCE. The primary source of information on historic and present-day dry cleaner locations was telephone directories which were available at the Fremont and Hayward Main Libraries. The earliest record of dry-cleaning businesses was in 1945. The addresses of the dry-cleaning businesses, the date their operation began and their years of operation were obtained and recorded. Businesses that were advertised as plants were noted. A plant was defined as a drycleaning business that used machinery to clean clothes on-site, as opposed to a business that served only as a drop-off site. Businesses listed as one-hour, four-hour, or same-day service were assumed to be plants and also noted. Directories were missing for the years of 1947, 1948, 1951, 1952, 1953, 1963, 1980, and 2006. Because these record gaps were three years or less, an assumption was made that those dry-cleaning businesses that operated prior to and after the record gap likely operated during the gap as well.

Some of the older businesses that operated prior to approximately 1960 were on streets that were later renamed or renumbered. For some businesses, the shopping mall and unit number were listed instead of a street address. Old newspaper clippings from the Fremont Main Library as well as communication with staff and volunteers from the Fremont Historical Society helped to identify the location of some of these businesses. In 
addition, older hard copy street maps published between 1930 and 1970, which were available at the University of California at Berkeley Map and Earth Sciences Library, the Fremont Main Library, and the Fremont Museum of Local History, were compared to newer maps in order to identify older streets. Through this method, some older businesses were partially located on renamed streets by street segment. The older street maps that were available did not show building or block address numbering. However, some 1944 Sanborn maps showed building numbering, and were useful in determining the location of one historic dry cleaner in Union City.

In order to further distinguish businesses as actual plants and potential sources of PCE, the list of dry-cleaning businesses from phone directories was compared to a list provided by the records department of the Bay Area Air Quality Management District (BAAQMD) of the names and addresses of permitted open and closed dry-cleaning plants and the type of solvent used by each. Due to some discrepancies between the phone directory and the BAAQMD list as to the year some plants closed, an additional cross-check was performed against the BAAQMD Toxic Air Contaminant Inventories for 2004, and from 2008 to 2011 that were available from the BAAQMD website. To further verify whether or not a dry cleaner used PCE, an additional cross-check was performed using a list provided by the ACWD of dry cleaners that were identified as having stored PCE on-site based on a 2004 survey comparing phone directory records and Hazardous Materials Management Plans (HMMPs) from fire departments. A final cross check was performed by examining HMMPs that were available for open and closed dry-cleaning businesses to further verify whether or not PCE was used and stored on-site, if and when 
its use and storage was discontinued, and the date of closure of the business if relevant. A final list of dry-cleaning businesses likely to be or have been plants that used PCE onsite was compiled.

The second part of the source assessment was to rank the potential of the plants to contaminate the basin with PCE. A scatter plot of the plants was created based on the number of years of operation, or duration, versus the year that the operation began, or age, similar to what was done in the vulnerability study of the Santa Clara basin by the Santa Clara Valley Water District (Mohr, 2007). Four threat rankings were created based on the approximate years in which the four generations of dry-cleaning machinery were introduced, using the assumption that dry cleaners that began operation using an earlier, less efficient generation of machinery that was more prone to leakage had a greater potential to release PCE into the groundwater.

Using ArcGIS 10, the ranked plants were geocoded and mapped. Street map data from SteetMap North America were used as a reference to create the address locator (ESRI, 2010). Several older cleaners, which with one exception stopped operation before 1960, could not be geocoded because the reference data set used consisted of newer street name and numbering. Therefore, these older cleaners were located at the street and street segment level only by comparing newer maps to older street maps. 


\section{Vulnerability Assessment}

The source assessment map with the threat-ranked dry cleaners was superimposed over the sensitivity maps of the subbasins in ArcGIS 10 to show the vulnerability of the groundwater to PCE contamination. 


\section{RESULTS}

\section{Sensitivity Assessment}

\section{BHF Subbasin}

The distribution of the borehole log and well locations that were used as a source of data and the interpolation of the data are shown on the aquifer and vadose zone media maps (Figs. 4, 5) and depth to water map (Fig. 6). The contouring does not continue to the southeast corner of the subbasin because data are not present there.

Based on the chosen categories and assigned sensitivity ratings, the aquifer media variable has areas of higher sensitivity that are interspersed with lower sensitivity areas from the fault to the central basin (Fig. 4). The soil drainage classification variable (Fig. 7) has one uniform high sensitivity area, with areas of lower sensitivity ratings extending from the central basin toward the San Francisco Bay. In contrast, the higher sensitivity areas of the vadose zone media variable (Fig. 5) are concentrated in the forebay area west of the fault, with a remaining low sensitivity area that extends toward the San Francisco Bay. Of note, all three of these variables have high sensitivity areas that coincide in the forebay area. In contrast, the variable of depth to water has mostly middle to lower sensitivity areas throughout the basin including in the forebay area, with the exception of sparse high-sensitivy areas in the southern part of the forebay region and the northern part of the BHF subbasin where the depth to the top of the aquifer is shallow (Fig. 6). 


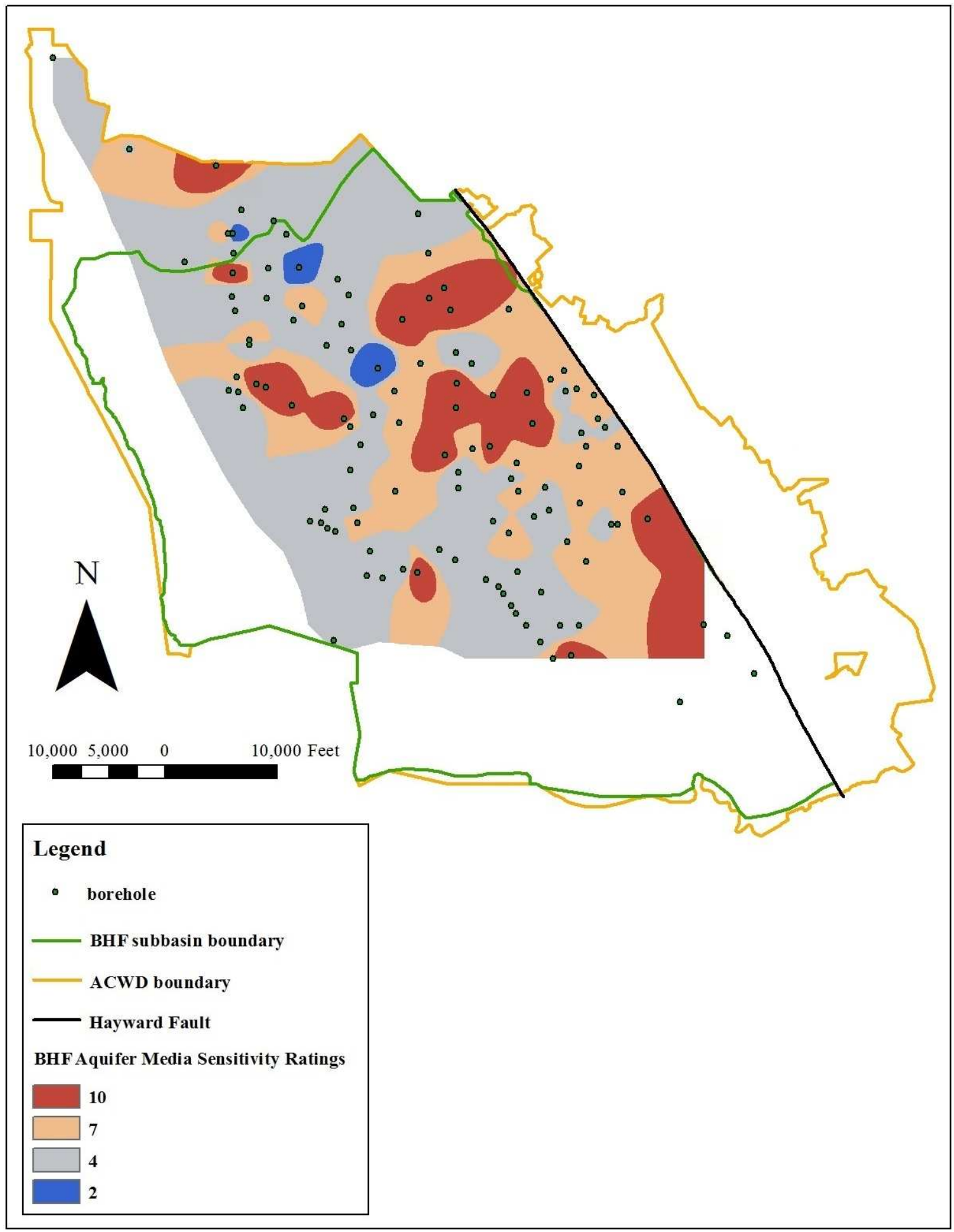

Figure 4. Aquifer media sensitivity ratings for the BHF subbasin. 


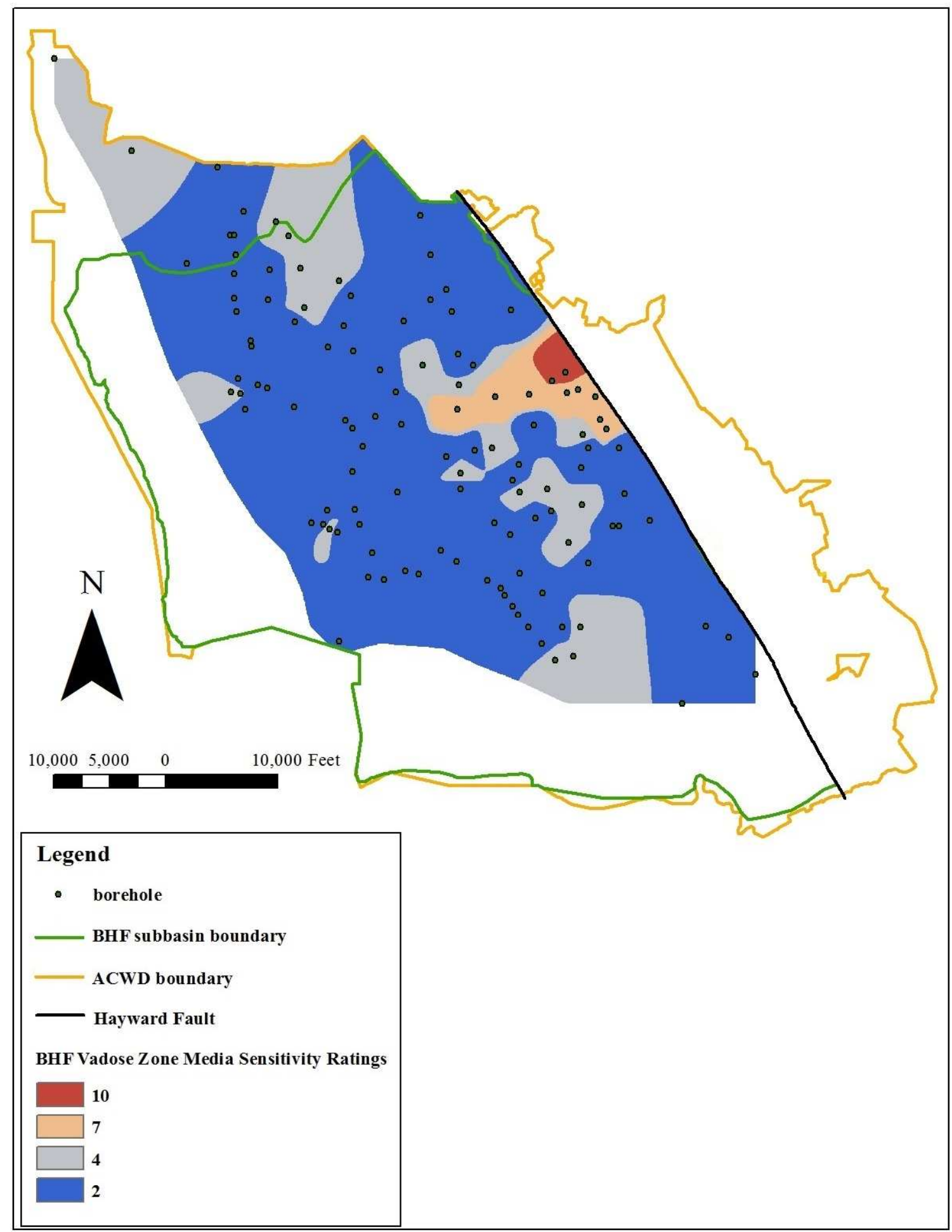

Figure 5. Vadose zone media sensitivity ratings for the BHF subbasin. 


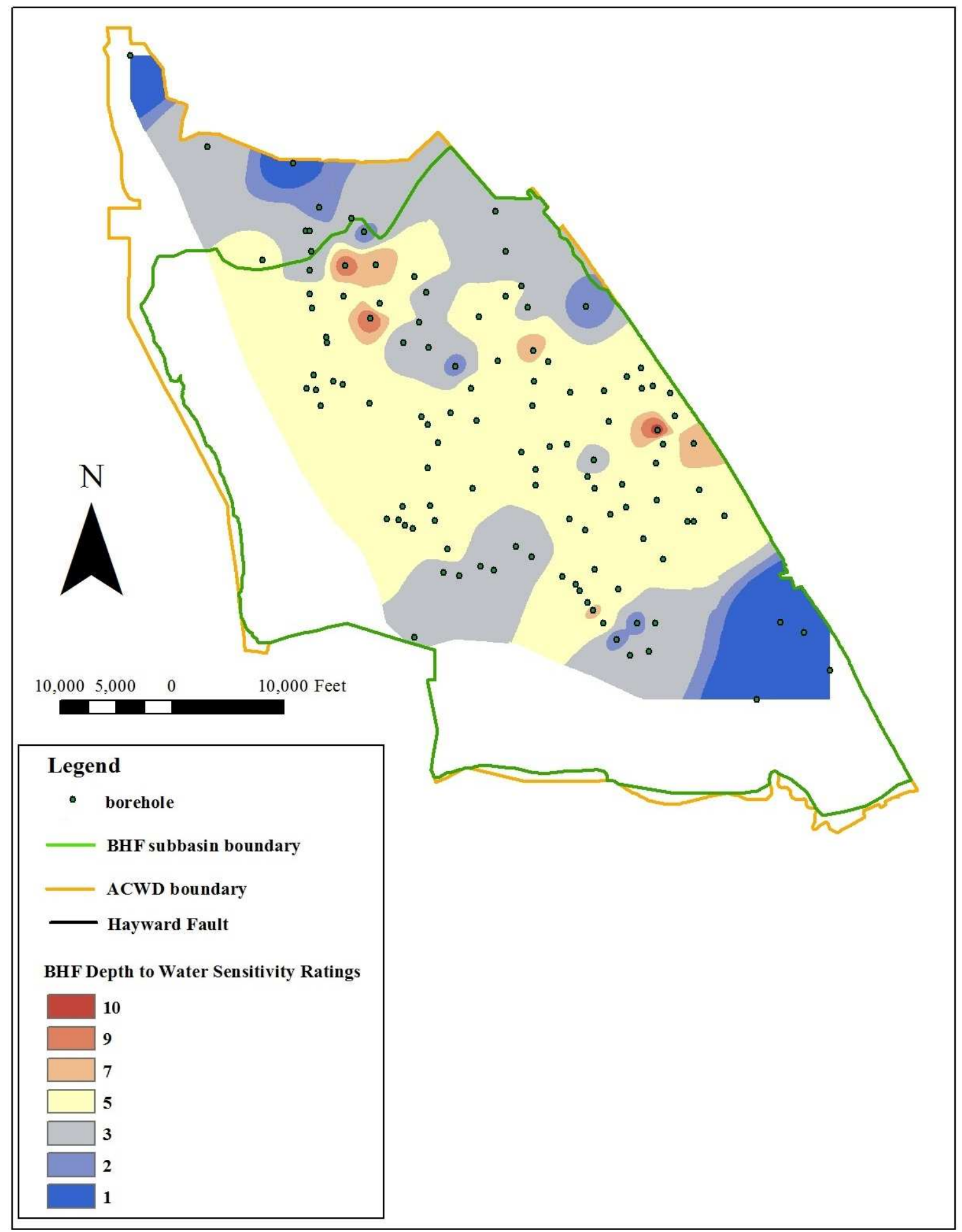

Figure 6. Depth to water sensitivity ratings for the BHF subbasin. 


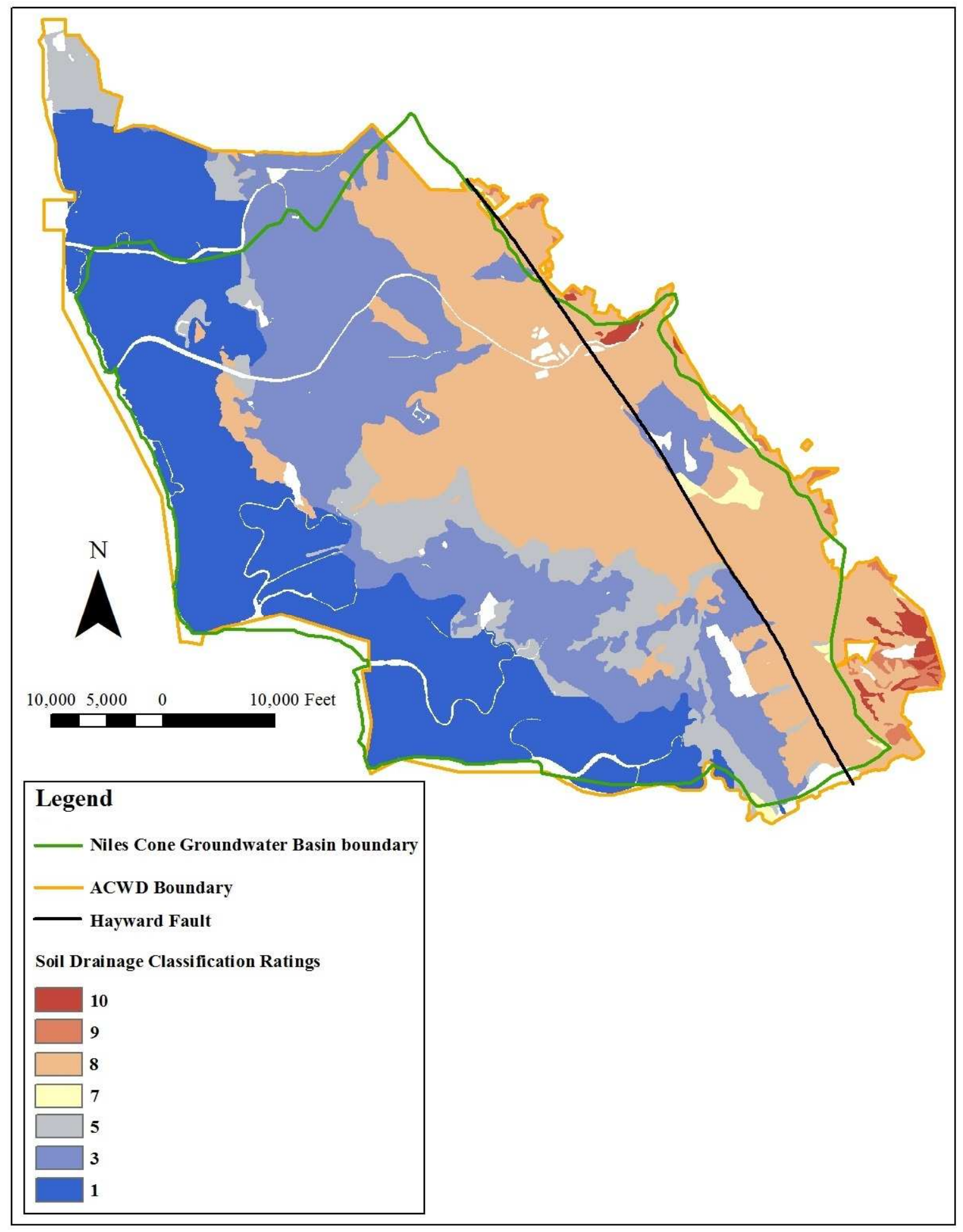

Figure 7. Soil drainage classification ratings for the Niles Cone Groundwater Basin. 
The final sensitivity map of the BHF subbasin is shown in Figure 8. The most sensitive area is the forebay region where the Alameda Creek intersects the fault. In comparing the hydrogeologic variable maps to the sensitivity map, the vadose zone and aquifer media are influential factors due their high sensitivity ratings in this area and their higher weighting factors of 5 and 3, respectively. Although the soil has a higher sensitivity rating of 8 in the forebay region, it contributes less to the sensitivity because it has a relatively lower weighting factor of 2 . Although the depth to the top of the aquifer has a higher weighting of 5, it was a less influential factor in the sensitivity of the forebay region due to its relatively lower sensitivity ratings in this area, with the exception of the sparse high-sensitivity areas at the southern portion of the forebay region, which coincide with the areas of high sensitivity from the aquifer media and vadose zone media.

Distal to the forebay area, both the aquifer media and soil drainage classification variables have areas rated with higher and lower sensitivity. In contrast, the vadose zone media variable consists only of lower sensitivity areas, and the depth to water variable consists predominantly of areas with lower and middle sensitivity ratings. Due to the higher weighting of 5 assigned to the vadose zone media and depth to water, these variables are the most influential factors in the low sensitivity west of the forebay region of the subbasin.

\section{AHF Subbasin}

In the AHF subbasin, the depth to water variable has high sensitivity areas southeast of the forebay region and middle to low sensitivity areas throughout the 


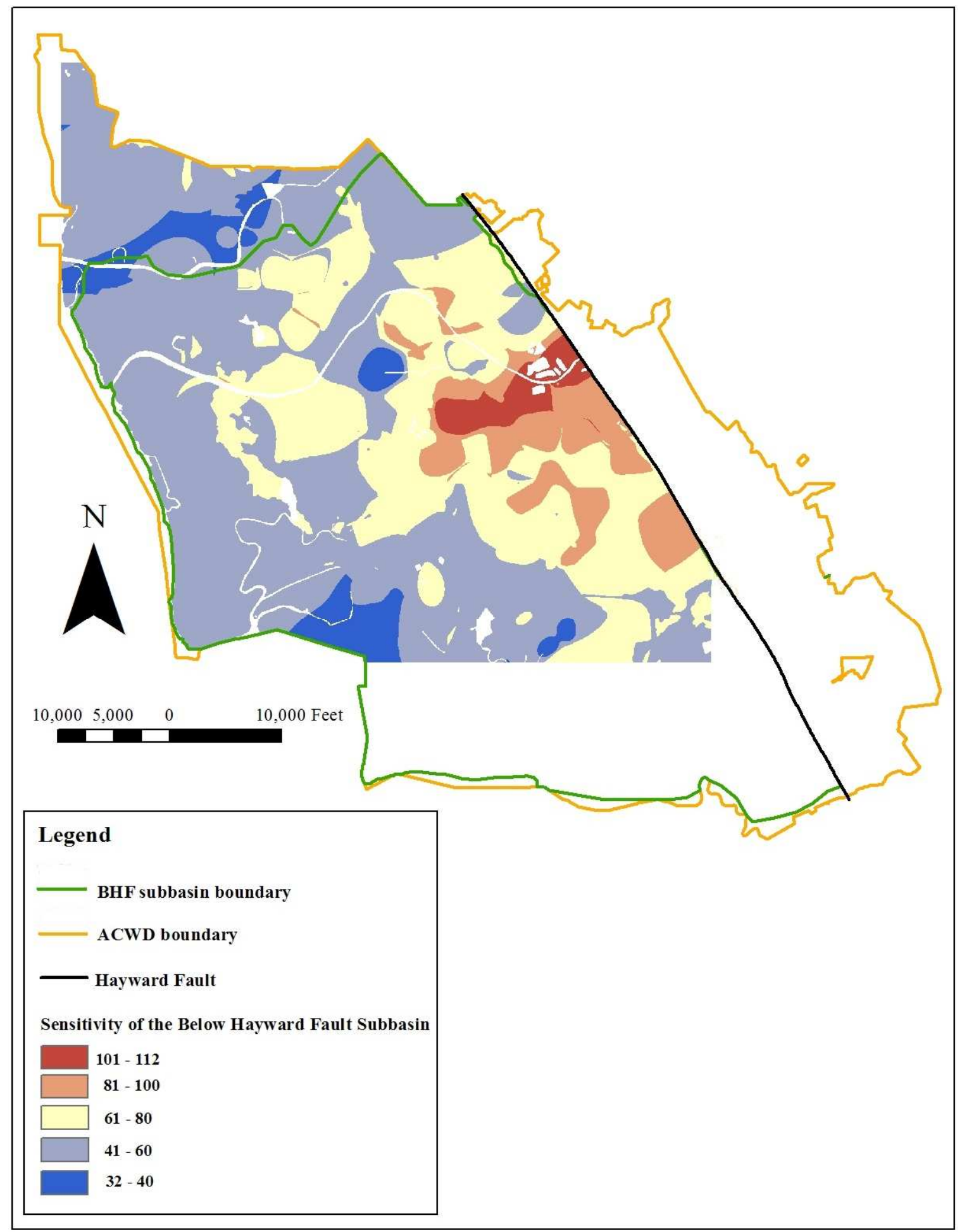

Figure 8. Sensitivity assessment of the BHF subbasin. 
remainder of the subbasin (Fig. 9). The vadose zone media variable has higher sensitivity areas are in the southeasternmost and northernmost extent of the mapped layer and lower sensitivity in all other areas (Fig. 10). Due to the same weighting of 5 that is assigned to each of these variables, the sensitivity of the subbasin is greatest where the areas of the more sensitively rated vadose zone and depth to water coincide (Fig. 11).

Most of the soil variable layer has a higher sensitivity, with the exception the central area which as a lower sensitivity rating (Fig. 7). Because this lower sensitivity area occurs where both the vadose zone media and depth to water have middle to low sensitivity, soil contributes to the low sensitivity of the subbasin in this central area (Fig.

11). However, the areas where soil has higher sensitivity coincide with the lower and middle sensitivity areas of the vadose zone media and depth to water (Figs. 7, 9, 10). Because of its lower weighting factor compared to the higher weighting factors of the vadose zone media and depth to water, soil does not contribute to the sensitivity in the rest of the subasin (Fig. 11).

\section{Source Assessment}

The final list of 72 dry-cleaning businesses likely to be or to have been plants that used PCE on-site is provided in Appendix A. The scatter plot of the plants based on the 


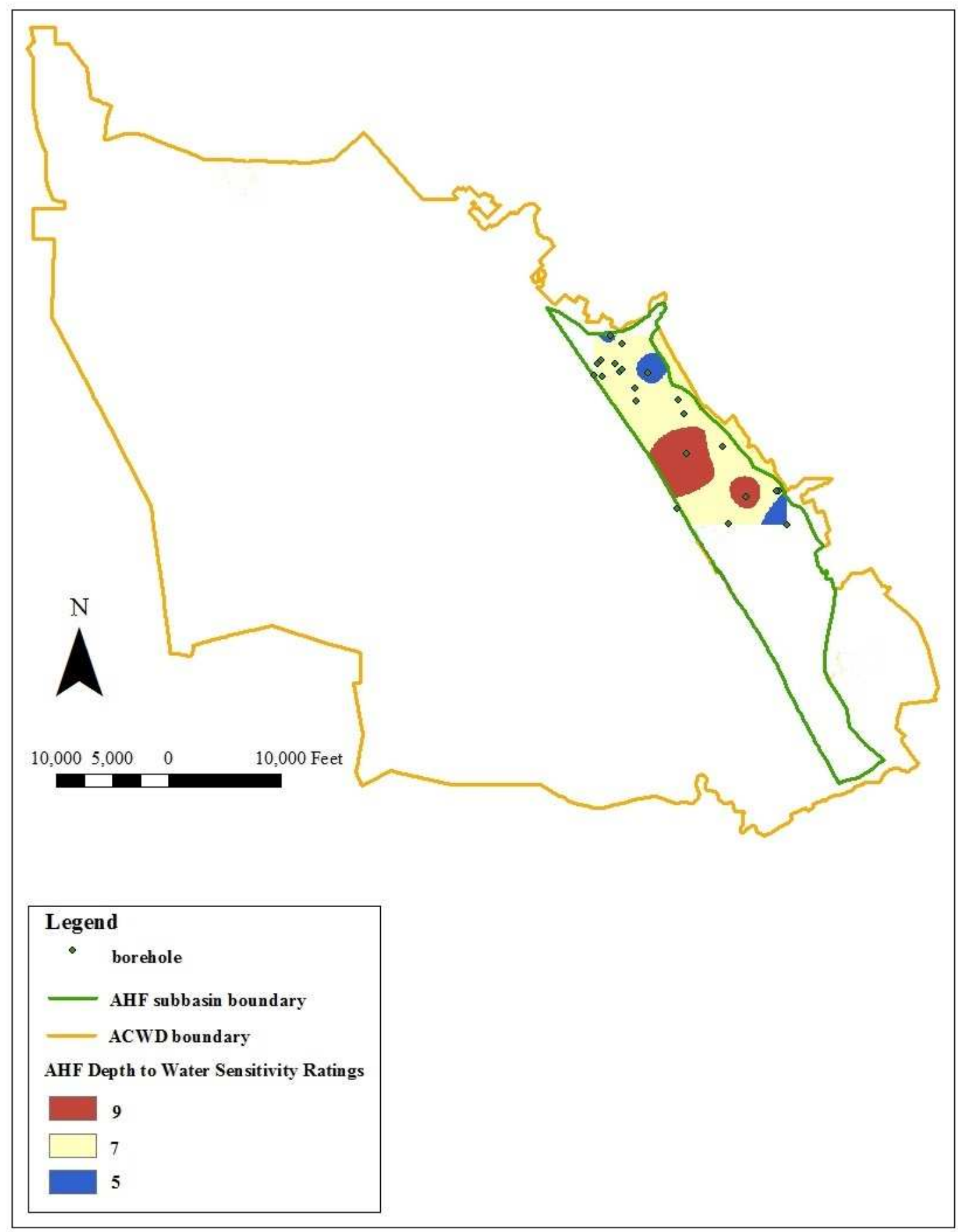

Figure 9. Depth to water sensitivity ratings for the AHF subbasin. 


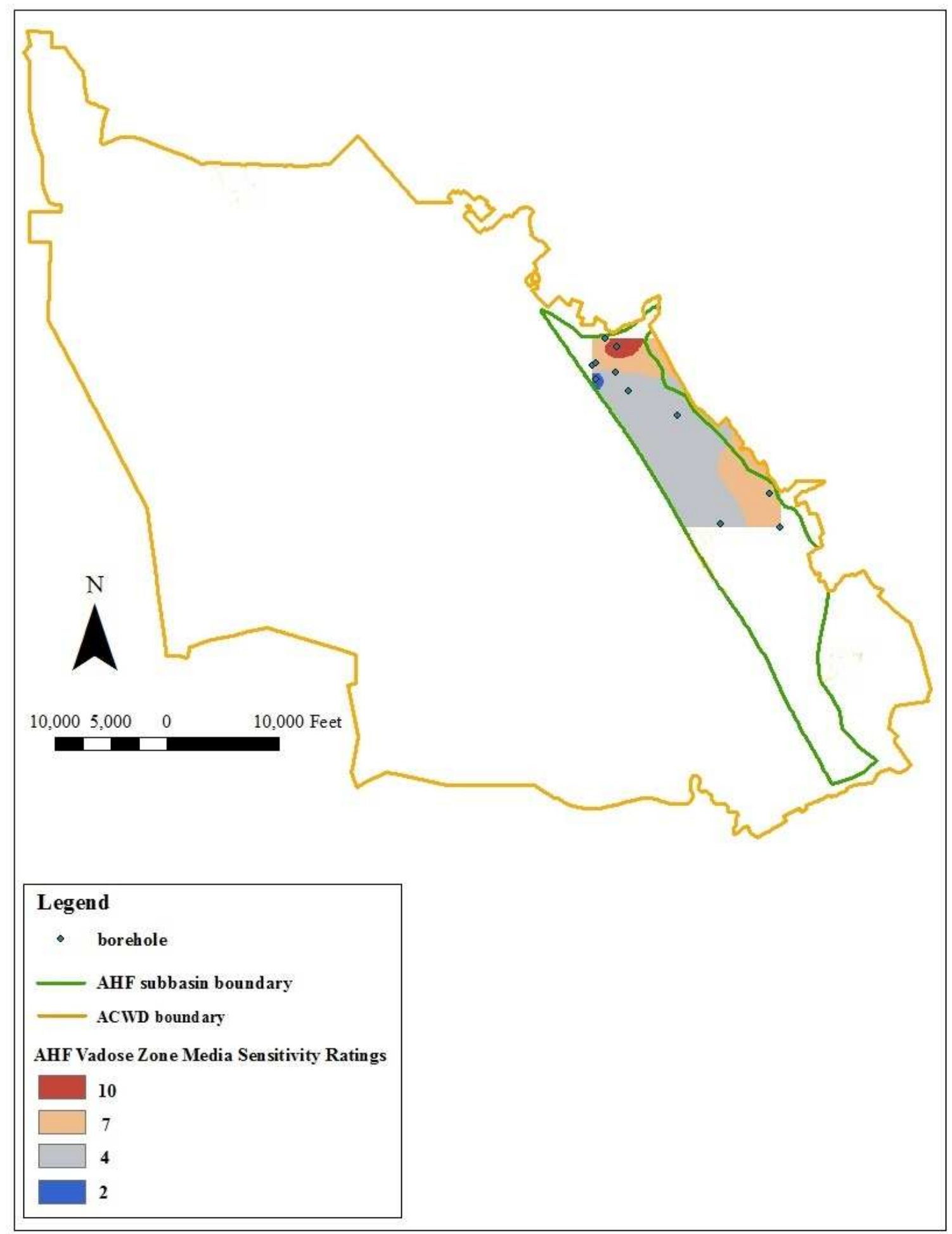

Figure 10. Vadose zone media sensitivity ratings for the AHF subbasin. 


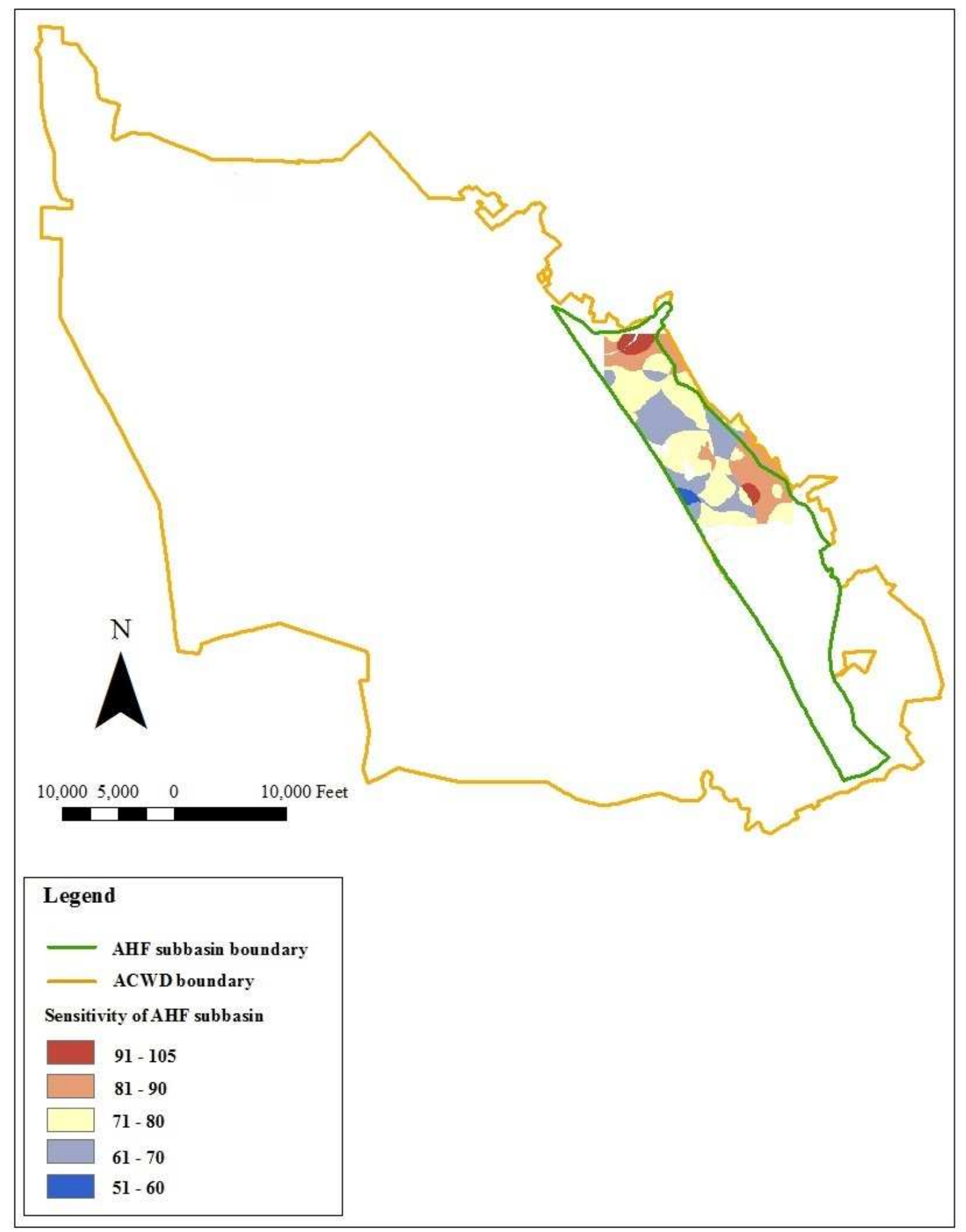

Figure 11. Sensitivity of the AHF subbasin. 
number of years of operation versus the year that the operation began along with the threat ranking of dry cleaners based on the approximate year that each generation of machinery was introduced are shown in Figure 12. A map of the locations of the geocoded ranked plants in the two subbasins is shown in Figure 13. The higher threat dry cleaners of rankings 4 and 3 are located on, or immediately adjacent to, the main streets that existed prior to the incorporation of Newark, Fremont, and Union City in 1955, 1956, and 1959 , respectively.

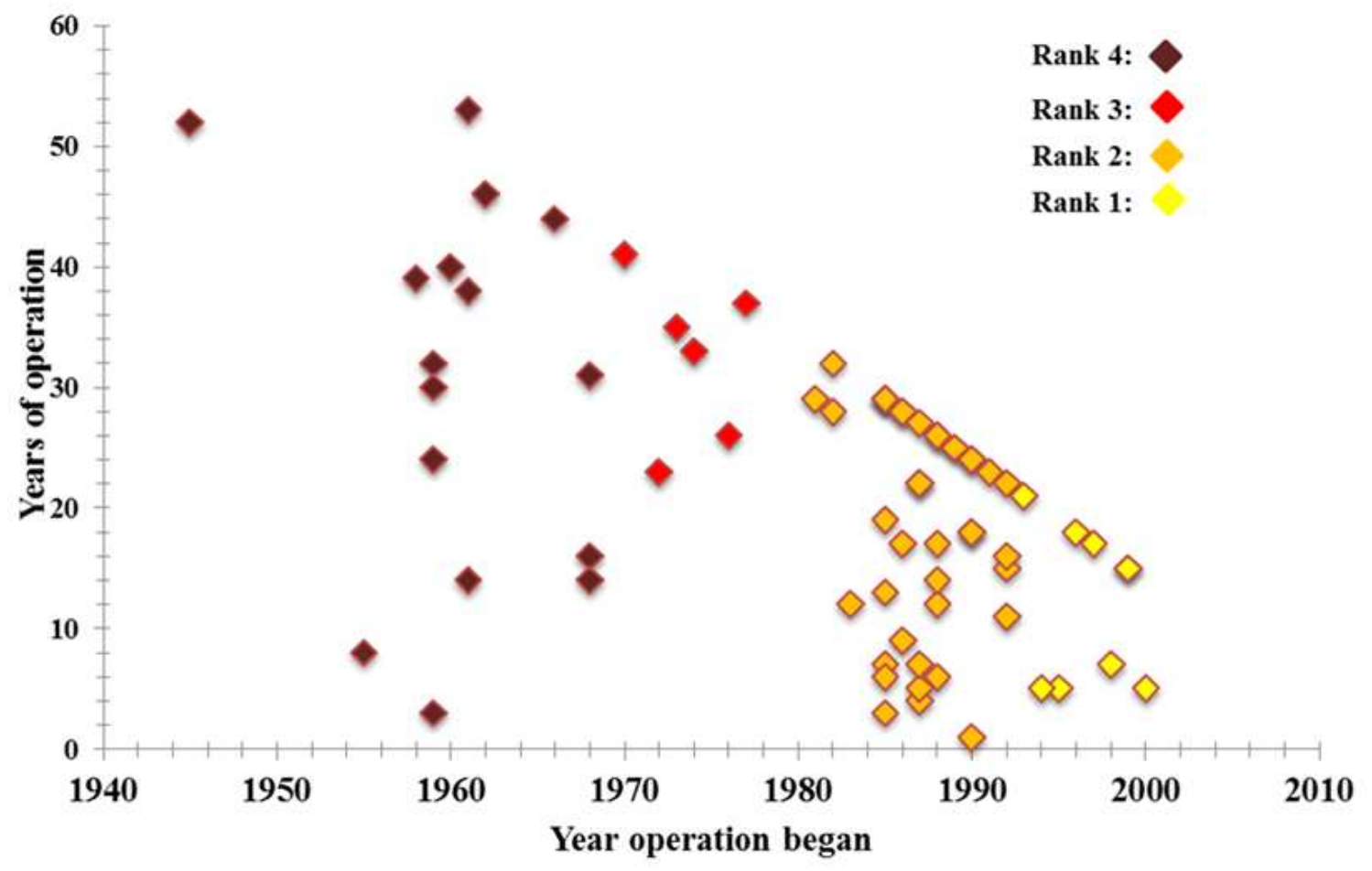

Figure 12. Threat ranking of dry-cleaning plants based on generation of machinery. 


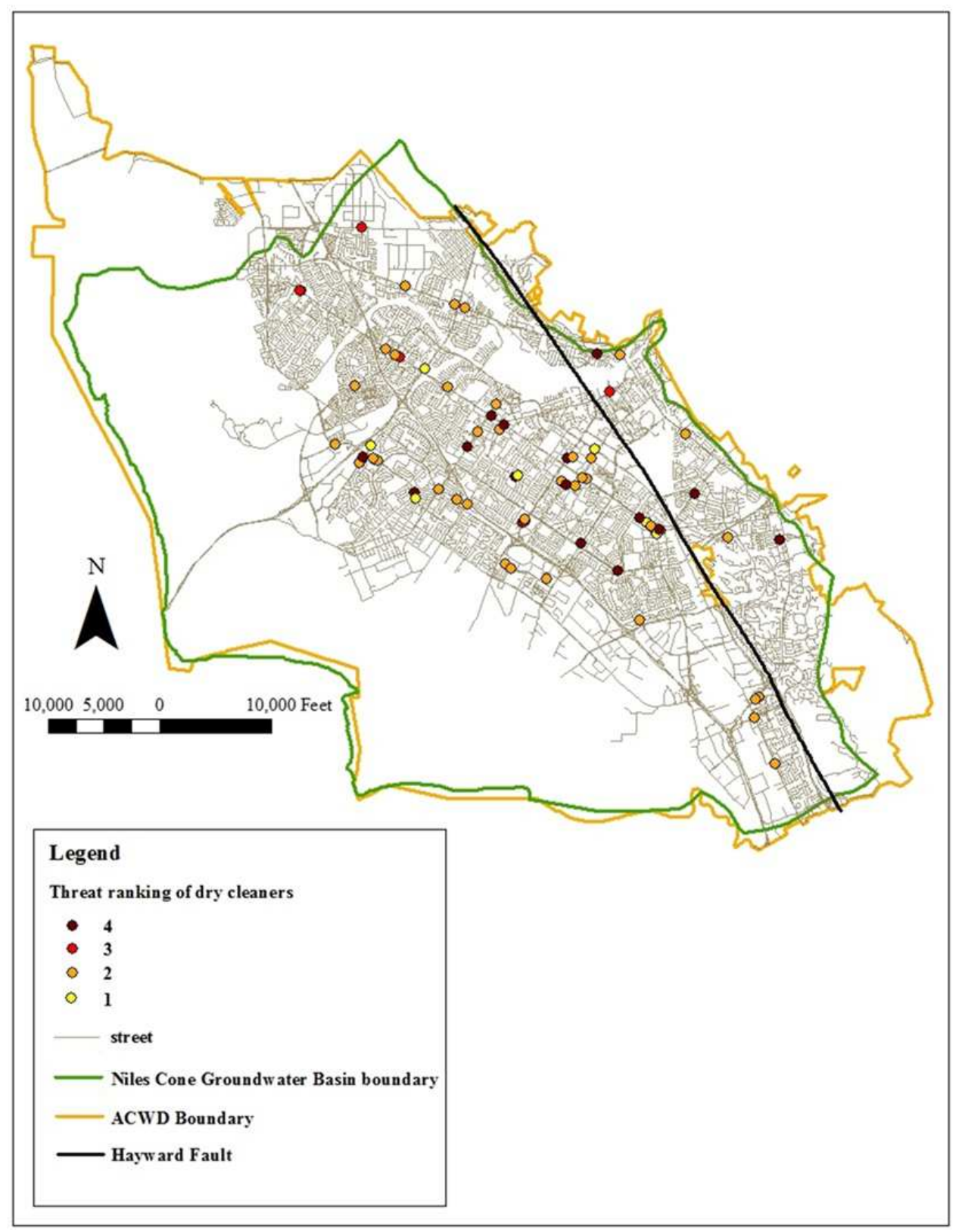

Figure 13. Ranked dry-cleaning plants in study area (extracted from ESRI, 2010).

Older cleaners that could not be geocoded and were located at the street and street segment level are listed in Appendix B. One older cleaner address could not be located. Maps of the located older cleaners are in Appendix C. Two of the older cleaners were 
determined to be likely plants. Dry cleaning businesses that were determined as less likely to be plants are listed in Appendix D.

\section{Vulnerability Maps}

The vulnerability maps for each subbasin are presented in Figures 14 and 15. Enlargements of the BHF subbasin vulnerability map where dry cleaners were closely spaced are presented in Appendix E. The maps show high-threat and lower-threat dry cleaners over both very sensitive areas and less sensitive areas. In the BHF subbasin, the area of highest vulnerability is in the forebay area. The AHF subbasin has fewer vulnerable areas, with higher-threat dry cleaners located over less sensitive areas. Vulnerability maps based on cleaners for which the plant status is uncertain are presented in Appendix F. 


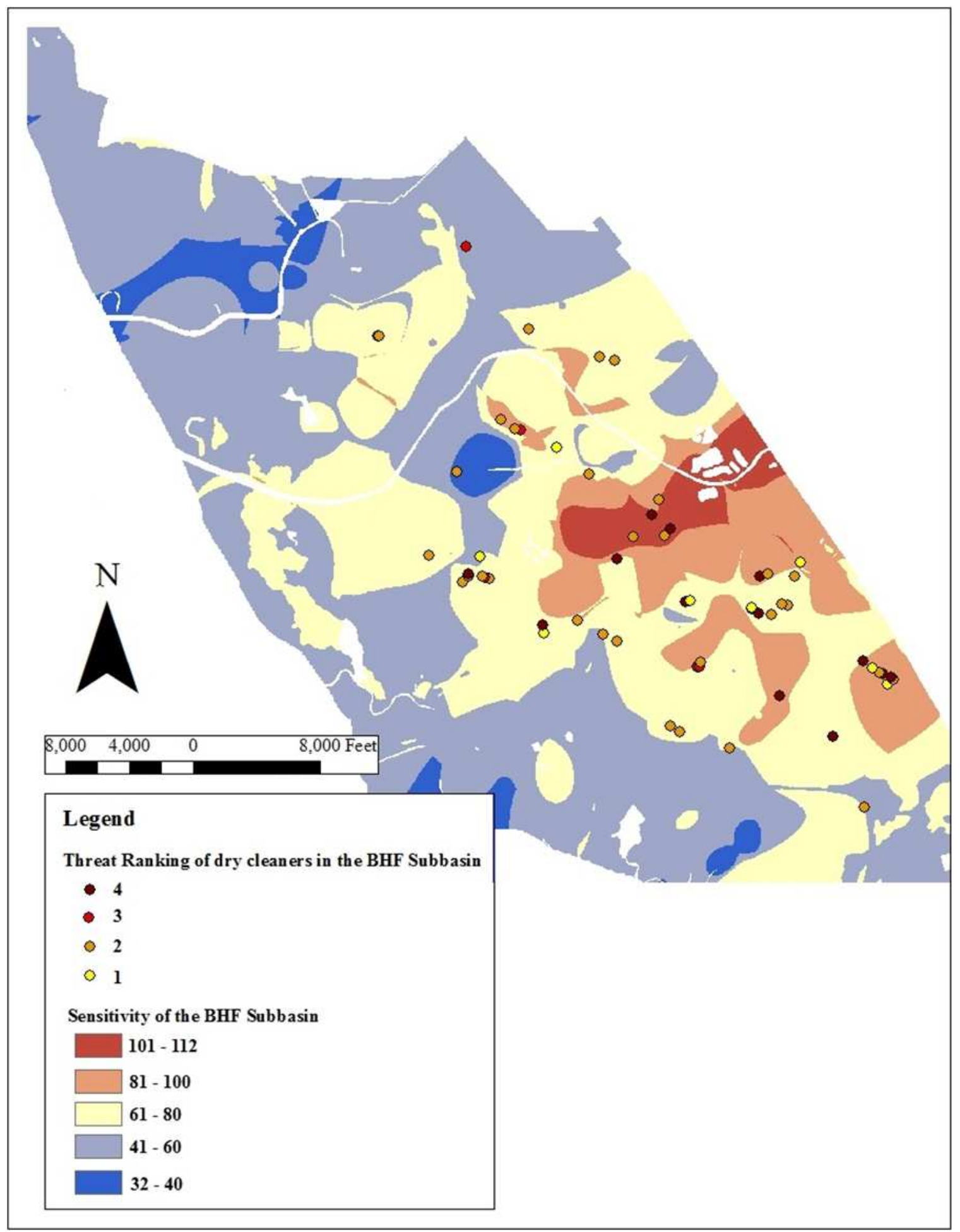

Figure 14. Vulnerability map of the BHF subbasin. 


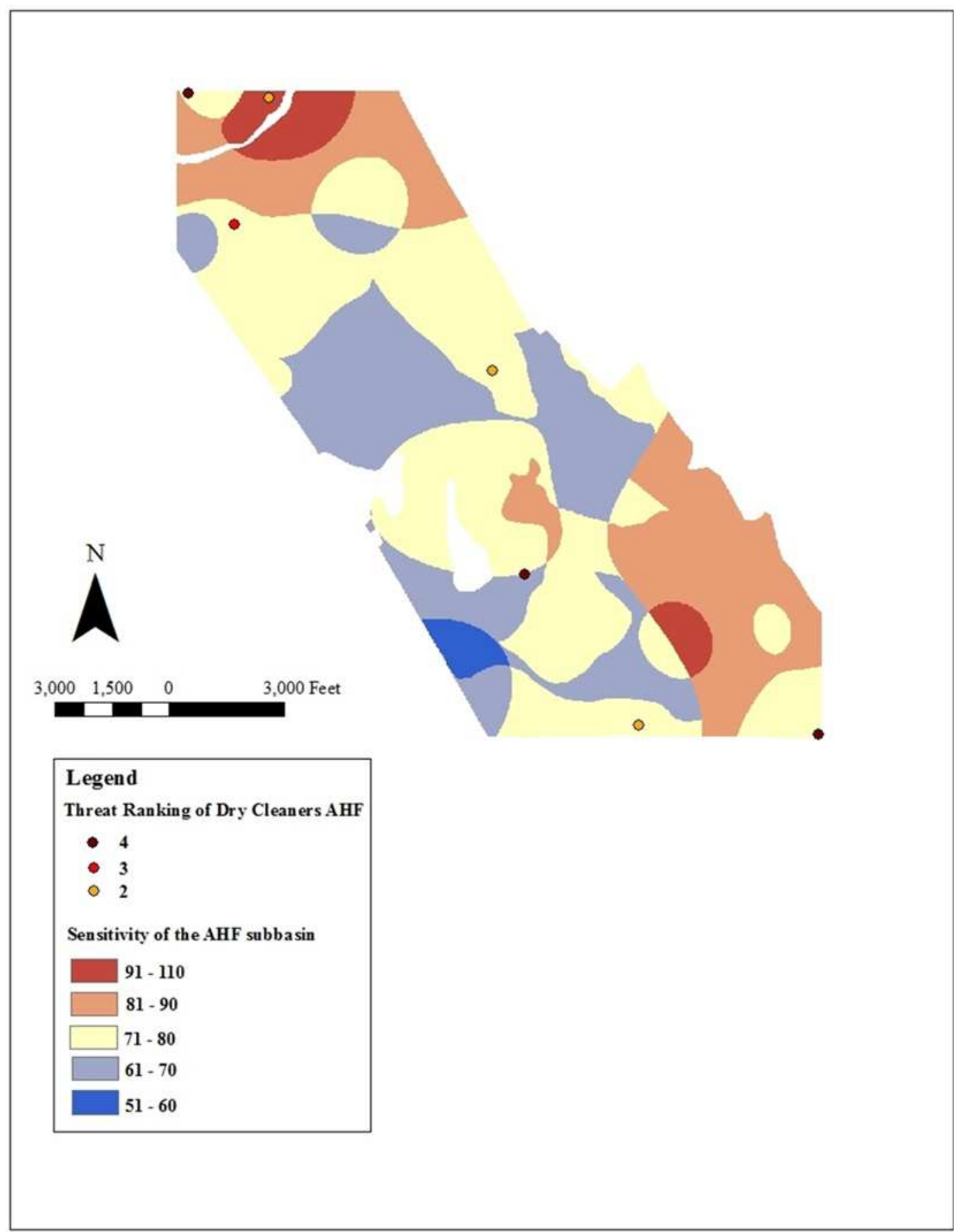

Figure 15 . Vulnerability map of the AHF subbasin. 


\section{DISCUSSION}

\section{Sensitivity Assessments}

Compared to the larger regional aquifer systems that have been evaluated using the DRASTIC method, the aquifer system of the Niles Cone Groundwater Basin is geologically uniform, with only alluvial and stream channel deposits. By modifying the DRASTIC method to the Niles Cone Groundwater Basin by categorizing the aquifer media and vadose zone media based on a thickness-weighted average of grain size, a more accurate and certain sensitivity assessment was obtained, particularly of the BHF subbasin. Although the AHF aquifer is known to be mostly sand and gravel, the borehole logs for the AHF subbasin did not go deep enough to include the necessary stratigraphic data for it. Therefore, aquifer media could not be included as a variable for the AHF subbasin.

Although the borehole log and well coverage was more uniformly distributed in the BHF subbasin, it does not extend completely to the southern boundary of the subbasin. In addition, the three southeasternmost borehole logs, which range in depth from 36 to $39 \mathrm{~m}$ (120 to $127 \mathrm{ft}$ ), do not contain stratigraphic data for the Newark Aquifer because it was not encountered at the depth of the bottom of the boreholes. When using the weighted sum overlay tool in ArcGIS, if there are no data in the overlying cells of any of the input raster variable layers, then the resulting raster cells of the output weighted sum analysis will have no data. Therefore, when the sensitivity analysis was performed, 
the absence of aquifer media stratigraphic data in the southernmost boreholes further truncated the sensitivity map in the southernmost portion. However, based on the significant depth to the top of the aquifer in that region, the sensitivity is likely very low.

Another contribution to uncertainty is that the category ranges and sensitivity were subjectively assigned. Because dry-cleaning operations are sources of point-source contamination, an attempt was made to calibrate the sensitivity ratings to organic solvent water quality data that is point-source in the Newark Aquifer using nonparametric statistics. Borehole logs from monitoring wells at contamination sites were available from the State Water Resources Control Board's GeoTracker website, and these were examined to find wells with screened intervals below the top of the Newark Aquifer that were documented as having organic solvent contamination. Thirty eight wells screened in the Newark aquifer were found, a number below the one hundred wells considered to be required for statistical significance (Panagopoulos et al., 2006). Thus, it was not possible to calibrate the sensitivity assessments.

It should be noted that the map layers of the aquifer media and vadose zone media do not delineate specific paleoenvironments such as alluvial fans and stream channels. Accurate representation of the paleoenvironments is impeded by the use of thicknessweighted averaging of rated grain size, as well as the distance between adjacent interpolated borehole $\operatorname{logs}$, which was locally as much as 1,500 m (5,000 ft).

However, although the paleogeography is not accurately delineated, the sensitivity ratings of the aquifer media, depth to water, and vadose zone media variables (Figs. 4-6) generally reflect the geologic history of the study area. The aquifer media 
map reflects a trend of westward decreasing grain size. The high sensitivity ratings of the aquifer media with a greater proportion of gravel are in the forebay area west of the fault in the eastern central area of the basin. These high ratings reflect the coarser materials that the Alameda Creek has deposited for the past 600,000 years as it has flowed from the Diablo Range (CDWR, 1973). The higher sensitivity area at the southeastern area of the basin could be from deposition of other streams coming from the Diablo Range. The generally lower sensitivity towards the Bay reflects the finer grained material such as clay and silt that have been deposited in the lower reaches of the fluvial system (CDWR, 1973).

The lower sensitivity areas interspersed throughout the higher sensitivity areas in the central and eastern portions of the aquifer media layer are due to clay stringers within the sand and gravel. Both the lower sensitivity areas related to the clay stringers as well as the smaller, high-sensitivity areas of coarser-grained deposits distal to the forebay can be interpreted as reflecting the deposition from braided and meandering streams radiating from the fan (CDWR, 1973). The sparse, high-sensitivity areas of the plot of the depth to the top of the aquifer can be interpreted as stream channel deposits.

In the map of the vadose zone media variable, the highest sensitivity is in the unconfined forebay area where the material consists of gravel and sand, reflecting areas where the Alameda Creek has eroded the fine grained Newark Aquitard and exposed the coarser alluvial fan material deposited by the creek. The sensitivity is much lower distal to the forebay, due to the clays and silts that were deposited further out on the alluvial 
fans as well as the deposition of estuarine and bay deposits during an interglacial cycle (CDWR, 2003).

Using the chosen rating categories, the sand lenses of the shallow aquifer contribute less to the vadose zone media sensitivity than expected. In the vadose zone media variable map, there are two boreholes in the vicinity of the unconfined forebay area where the shallow aquifer occurs that have average grain size ratings in the range of 6 to 7 and a sensitivity rating of 7 . Otherwise, the rest of the vadose zone where the shallow aquifer occurs has average grain sizes ranging from 1 to 4 with sensitivity ratings of 2 and 4 (Fig. 5) due to the shallow aquifer being relatively thin compared to the thickness of the vadose zone. Similar to the original DRASTIC index method, the purpose of using aquifer media as a variable in the sensitivity assessment is to take into consideration the rate of spread of contamination and the time for the attenuation of contaminant to take place. Therefore, this variable represents the media's permeability and does not reflect the transmissivity, which incorporates the actual thickness of the aquifer. For example, the thickness of the Newark Aquifer at the southeasternmost

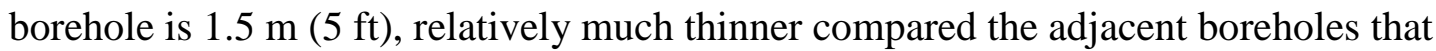
record the aquifer thickness to be 14 and $15 \mathrm{~m}$ (47 and $50 \mathrm{ft}$ ) (Fig. 4). However, all three boreholes have the same sensitivity rating based on the permeability of the material, and the interpolation of the three boreholes based on the category ratings shows a highly sensitive area.

For the AHF subbasin, the borehole log and well data are more geographically restricted, contributing to a sensitivity map that is truncated in the northern and 
southernmost portions of the basin (Figs. 9-11). In addition, there is a less uniform distribution of borehole logs containing vadose zone data in the central southern area of the subbasin, contributing to more uncertainty in the interpolation of point data for the vadose zone media.

For the AHF subbasin, the vadose zone is less sensitive than expected, given that the aquifer in the AHF subbasin is known to be coarse-grained and mostly unconfined. Although the north and southeast areas are sensitive, the central area is not.

\section{Source Assessments}

There is good certainty based on telephone directories and on BAAQMD and HMMP records that the dry cleaners identified in the source assessment were or currently are plants that used or use PCE on-site during most or all of their duration of operation. Although almost all of the dry cleaners that were identified as likely plants were geocoded, the reconfiguring of blocks and streets over the years can be a possible source of error.

Due to the unavailability of reliable and consistent records on solvent mileage and dry-cleaning-machinery usage, the threat of a dry cleaner based on the potential amount of PCE released could not be determined quantitatively. Rather, the threat of a dry cleaner to contaminate with PCE was categorized qualitatively based on the year that a dry cleaner began operation, or its age, in relation to the approximate year each generation of dry-cleaning machinery was introduced. Therefore, it is difficult to justify 
the use of the number of years that a cleaner operated, or its duration, as a marker as was done in the in the age-duration threat ranking that was used in the SCVWD dry cleaning vulnerability study (Mohr, 2007).

There is some uncertainty in assigning a threat rank based on age and the year that each generation of machinery was introduced. The use of first-generation machinery was not banned in California until 1998, about 30 years after second-generation machinery was introduced, and the use of second-generation machinery was banned in 2004 (Jacobs Engineering, 2004; Mohr, 2007). Therefore, although it is likely that at least some established operational dry-cleaning plants began using new machinery when it was introduced, it is uncertain how many did. Therefore, it is difficult to justify the accuracy of an age-duration relationship in threat ranking.

\section{Vulnerability Maps}

Because the BHF subbasin sensitivity map (Fig. 8) is truncated in the southern portion of the Niles Cone Groundwater Basin, this subbasin's vulnerability does not take into account the four southeasternmost dry cleaning plants whose locations were geocoded. However, these are less threatening dry cleaners with a lower threat ranking of 2 , and the sensitivity in this area of the basin is likely low due to the large depth to the top of the aquifer. Although the AHF sensitivity map is truncated in the southern and northernmost areas of the subbasin, all of the confirmed dry cleaning plants in this subbasin are located within the extent of the sensitivity map (Fig. 15). 
Given that the source assessment threat rankings were more qualitative compared to the sensitivity assessment index methodology, a summed overlay analysis of the two layers was not performed in ArcGIS. Rather, the vulnerability map consists of having the source assessment map overlie the sensitivity map. However, having a separate source assessment map overlying a sensitivity map can be advantageous in that a regulatory agency may want to prioritize the investigation of a dry cleaner with a lower threat ranking that is in a highly sensitive area of the basin. 


\section{CONCLUSIONS}

Maps of both the BHF subbasin and the AHF subbasin were generated that show the vulnerability of the groundwater in the Niles Cone Groundwater Basin to PCE contamination from past and present dry-cleaning operations, based on sensitivity assessments of the subbasins and a dry cleaner source assessment. One can discern on the sensitivity maps the areas where the groundwater is most susceptible to contamination. There is more certainty in the sensitivity assessment of the BHF subbasin compared to that of the AHF subbasin due to the availability of aquifer media data as well as a better distribution geographically of borehole log and well data. The most sensitive region in the BHF subbasin is the forebay area due to a higher proportion of coarse-grained material in the aquifer and vadose zone media and a thinner to absent aquitard due to deposition from the Alameda Creek for the past 600,000 years.

In the source assessment, past and present dry cleaners were identified with good certainty. Although the assigned threat rankings are qualitative, they allow one to identify and evaluate dry cleaners of higher threat or greater concern. Dry cleaners of higher threat can be identified over areas of higher sensitivity in the vulnerability maps, indicating areas that are potentially vulnerable to PCE contamination from dry cleaners. The vulnerability maps also allow one to identify cleaners of higher threat located over lower sensitivity areas of the subbasins. The vulnerability maps, especially that of the BHF subbasin, can serve as a screening tool for regulators and water managers to help 
prioritize dry cleaning contaminant investigation based on basin sensitivity and the potential threat from dry cleaners. 


\section{REFERENCES CITED}

Alameda County Community Development Agency (Alameda County CDA), 2012, Alameda County city boundaries, shapefiles, https://www.acgov.org/government/geospatial.htm (accessed July 2013).

Alameda County Water District (ACWD), 2010, Urban water management plan, 20102015, 244 p., http://www.acwd.org/uwmp.php5 (accessed January 2012).

Alameda County Water District (ACWD), 2012, Groundwater Monitoring Report 2011, $61 \mathrm{p}$.

Aller, L., Bennett, T., Lehr, J.H., Petty, R.J., and Hackett, G., 1987, DRASTIC: a standardized system for evaluating groundwater pollution potential using hydrogeologic settings, June 1987: United States Environmental Protection Agency (USEPA) Report 600/2-87/035, 622 p.

Alley, W.M., Reilly, T.E., and. Franke, O.L., 1999, Sustainability of ground-water resources: U.S. Geological Survey Circular 1186, 79 p.

Antonakos, A.K., and Lamrakis, N.J., 2007, Development and testing of three hybrid methods for the assessment of aquifer vulnerability to nitrates, based on the DRASTIC model, and example from NE Korinthia, Greece: Journal of Hydrology, v. 333, p. 288-304.

California Department of Water Resources (CDWR), 1973, Evaluation of groundwater resources, South Bay, Volume 2 Additional Fremont study area: Bulletin No. 118$1,58 \mathrm{p}$.

California Department of Water Resources (CDWR), 2003, California's groundwater, Bulletin 118, Update 2003, 246 p.

California Department of Water Resources (CDWR), 2013, California's groundwater: Bulletin 118, Groundwater basin maps and descriptions, shapefile, http://www.water.ca.gov/groundwater/bulletin118/gwbasin_maps_descriptions. cfm (accessed December 2013).

California Regional Water Quality Control Board (CRWQCB), 2003, A comprehensive groundwater protection evaluation for the south San Francisco Bay basins, 238 p.

Cioco, Ramon W., 2012, Hydrostratigraphy of the shallow aquifer in the Niles Cone Groundwater Basin, [Master's thesis]: San José State University, 52 p. 
Domenico, P.A., and Schwartz, F.W., 1998, Physical and chemical hydrogeology: New York, John Wiley and Sons, Inc., 506 p.

Environmental Systems Research Institute (ESRI), 2010, StreetMap North America.

Environmental Systems Research Institute (ESRI), 2013a, World shaded relief, shapefile, http://www.arcgis.com/home/item.html?id=9c5370d0b54f4de1b48a3792d7377ff2 (accessed July 7, 2013).

Environmental Systems Research Institute (ESRI), 2013b, World reference overlay, shapefile,

http://www.arcgis.com/home/item.html?id=9763d83ba63048da8a2e0a71ccea441

6 (accessed July 7, 2013).

Focazio, M.J., Reilly, T.E., Rupert, M.G., and Helsel, D.R., 2002, Assessing groundwater vulnerability to contamination: providing scientifically defensible information for decision makers: U.S.Geological Survey Circular 1224, 33 p.

Jacobs Engineering, 2004, Viable alternatives to perchloroethylene in dry cleaning: City of Los Angeles Environmental Affairs Department, 75 p.

James M Montgomery Consulting Engineers, Inc., 1991, Alameda County Water District integrated groundwater-surface water model, September 1991, 202 p.

Mohr, T.K., 2007, Study of potential for groundwater contamination from past dry cleaner operations in Santa Clara County: Santa Clara Valley Water District (SCVWD), 203 p.

Moran, J. E., Hudson, G.B., Eaton, G. F., and Leif, R., 2002, A contamination vulnerability assessment for the Livermore-Amador and Niles Cone Groundwater Basins: Livermore National Laboratory (LLNL), UCRL-AR-148831. 25 p.

National Research Council (NRC), 1993, Ground water vulnerability assessment: contamination potential under conditions of uncertainty: Washington, D.C., National Academy Press, 210 p.

Panagopoulos, G.P., Antonakos, A.K., and Lambrakis, N.J., 2006, Optimization of the DRASTIC method for groundwater vulnerability assessment via the use of simple statistical methods and GIS: Hydrogeology Journal, v. 14, p. 894-911

Papler, R., 2011, Staff report on dry cleaner spills: San Francisco Bay Regional Water Quality Control Board, (SFBRWQCB), 6 p. 
Rupert, M.G., 2001, Calibration of the DRASTIC ground water vulnerability mapping method: Ground Water, v. 30, p. 625-630.

San Francisco Bay Regional Water Quality Control Board (SFBRWQCB), 2013, Site cleanup program:

phttp://www.swrcb.ca.gov/sanfranciscobay/sitecleanupprogram.shtml (accessed January 2012).

Scanlon, B.R., Fount, C.C., Longuevergne, L., Reedy, R.C., Alley, W.M., McGuire, V.L., and McMahon, P.B., 2012, Groundwater depletion and sustainability of irrigation in the US High Plains and Central Valley: Proceeding of the National Academy of Sciences of the United States of America, v. 109, no. 24, p. 9320-9325.

Todd Engineers and Kennedy/Jenks Consultants, 2010, Revised final groundwater vulnerability study, Santa Clara County, California: Santa Clara Valley Water District, $92 \mathrm{p}$.

United States Census Bureau, 2013, Cartographic boundary shapefile, states, https://www.census.gov/geo/maps-data/data/cbf/cbf_state.html (accessed May 2014).

United States Department of Health and Human Services (DHHS), National Institute for Occupational Safety and Health (NIOSH), 1997, Control of exposure to perchloroethylene in commercial drycleaning (machine design): Publication No. 97-156, 4 p: http://www.cdc.gov/niosh/pdfs/hc18.pdf (accessed October 2012).

United States Environmental Protection Agency (USEPA), 2003, A review of methods for assessing aquifer sensitivity and ground water vulnerability to pesticide contamination, September 1993: EPA Number 813R93002, 147 p. 


\section{APPENDIX A. DRY-CLEANING PLANTS IN STUDY AREA}

Dry-cleaning businesses listed in phone directories were categorized as likely to be plants if they were verified as plants and potential sources of PCE based on BAAQMD records; if they were identified in phone books as plants, or as having fourhour or same-day service; or if they were identified by the ACWD as dry cleaners that stored PCE on-site and therefore likely to be plants. Businesses listed in phone directories that did not have confirmatory information of their status as plants were categorized as uncertain. The businesses that were labeled as uncertain were not included in the scatter plot in Figure 12. 
Table A1. Fremont dry cleaners likely to be or to have been plants

\begin{tabular}{|c|c|c|c|c|}
\hline business name & address & zip code & $\begin{array}{l}\text { year operation } \\
\text { began }\end{array}$ & $\begin{array}{l}\text { years of } \\
\text { operation }\end{array}$ \\
\hline Super Cleaners & 4150 Walnut Avenue & 94538 & 1987 & 27 \\
\hline Savings One Hour Cleaners & 39480 Fremont Blvd & 94538 & 1991 & 23 \\
\hline Arden Cleaners & 34747 Ardenwood Blvd & 94555 & 1992 & 22 \\
\hline Bo-Mar Cleaners & 34460 Fremont Blvd, \#A & 94555 & 1977 & 37 \\
\hline \#1 Cleaners and Alterations & 39250 Paseo Padre Pkwy & 94538 & 1997 & 17 \\
\hline Ardenwood Cleaners & 4946 Paseo Padre Pkwy & 94555 & 1988 & 26 \\
\hline Stars Cleaners & 46670 Mohave Blvd & 94539 & 1992 & 15 \\
\hline Mission Valley Holiday Cleaners & 40093 Mission Blvd & 94539 & 1990 & 18 \\
\hline \#1 Cleaners And Alterations & 47001 Warm Springs Blvd & 94539 & 1988 & 12 \\
\hline Elegant Cleaners & 47950 Warm Springs Blvd & 94539 & 1988 & 17 \\
\hline America Cleaners LLC & 1548 Washington Blvd & 94539 & 1992 & 16 \\
\hline State Cleaners Inc & 4565 Eggers Drive & 94536 & 2000 & 5 \\
\hline Township Cleaners & 43464 Ellsworth St & 94539 & 1961 & 53 \\
\hline Star Dry Cleaners & 5133 Mowry Avenue & 94538 & 1987 & 22 \\
\hline Tri-City Cleaners & 3924 Decoto Road & 94536 & 1995 & 5 \\
\hline Plaza Cleaners & 3932 Washington Blvd & 94538 & 1985 & 19 \\
\hline Quality Cleaner & 3607 Thornton Ave & 94536 & 1985 & 29 \\
\hline Pegasus Cleaners & 34257 Fremont Blvd & 94555 & 1986 & 28 \\
\hline Sparklizing Cleaners & 5200 Mowry Avenue, \#A & 94538 & 1974 & 33 \\
\hline Walnut Cleaners & 3367 Walnut Avenue & 94538 & 1985 & 29 \\
\hline Fremont French Cleaners & 4949 Stevenson Blvd & 94538 & 1962 & 46 \\
\hline United Dry Cleaner & 35754 Fremont Blvd & 94536 & 1990 & 24 \\
\hline Smart Cleaners & 41083 Fremont Blvd & 94538 & 1993 & 21 \\
\hline Kings Cleaners & 46521 Mission Blvd & 94539 & 1988 & 14 \\
\hline Holiday Cleaners & 39124 Fremont Hub & 94538 & 1994 & 5 \\
\hline Holiday Cleaners & 39126 Fremont Hub & 94538 & 1985 & 7 \\
\hline Fremont Holiday Cleaners & 34141 Fremont Blvd & 94555 & 1988 & 6 \\
\hline Pacific Pure Water and Cleaners & 40919 Fremont Blvd, \#12 & 94538 & 1981 & 29 \\
\hline State Cleaners Inc & 38340 Glenmoor Dr & 94536 & 1960 & 40 \\
\hline Hub Cleaners & 39238 Fremont Hub & 94538 & 1968 & 16 \\
\hline Township Cleaners & 3941 Washington Blvd & 94538 & 1959 & 32 \\
\hline Affordable Cleaners & 4133 Peralta Blvd & 94536 & 1983 & 12 \\
\hline Fremont Plaza Norge Cleaner & 39067 State Street & 94538 & 1982 & 28 \\
\hline Mission Cleaners & 2000 Driscoll Rd \#E & 94539 & 1961 & 38 \\
\hline Center Square Cleaners & 37070 Fremont Blvd & 94536 & 1945 & 52 \\
\hline Coronet Cleaners & 40645 Fremont Blvd & 94538 & 1958 & 39 \\
\hline Meadow Cleaners & 41200C Blacow Road & 94538 & 1966 & 44 \\
\hline State Cleaners & 5255 Mowry Avenue, \#P & 94538 & 1973 & 35 \\
\hline Delia's cleaners and drapery centers & 38003 Mission Blvd & 94536 & 1986 & 9 \\
\hline $\begin{array}{l}\text { Auto Mall Cleaners same day } \\
\text { service }\end{array}$ & 43432 Grimmer Blvd & 94538 & 1985 & 29 \\
\hline Henry Miller cleaning service & 37365 Fremont Blvd & 94536 & 1959 & 24 \\
\hline Delias cleaners and drapery centers & 39411 Fremont Blvd & 94538 & 1985 & 3 \\
\hline Irvington Launderette and Cleaners & 40955 Fremont Blvd & 94538 & 1959 & 3 \\
\hline Niles City Cleaners & $161 \mathrm{I} \mathrm{St}$ & 94536 & 1955 & 8 \\
\hline Warm Springs cleaners & 46650 Mohave Dr & 94539 & 1987 & 5 \\
\hline Norge village laundry and cleaning & 3766 Mowry Ave & 94538 & 1968 & 14 \\
\hline Delias cleaners and drapery centers & 4366 Thornton Ave & 94536 & 1986 & 28 \\
\hline Ralphs Cleaners & 4673D Thornton Ave & 94536 & 1959 & 30 \\
\hline All-Star Dry Cleaners & 40811 Fremont Blvd & 94538 & 1998 & 6 \\
\hline
\end{tabular}


Table A2. Newark dry cleaners likely to be or to have been plants

\begin{tabular}{|l|l|l|l|l|}
\hline business name & address & $\begin{array}{l}\text { zip } \\
\text { code }\end{array}$ & $\begin{array}{l}\text { year operation } \\
\text { began }\end{array}$ & $\begin{array}{l}\text { years of } \\
\text { operation }\end{array}$ \\
\hline Sparkling Cleaners & 39253 Cedar Blvd & 94560 & 1989 & 25 \\
\hline Villa One Hr Cleaners & 36601 Newark Blvd, \#70 & 94560 & 1999 & 15 \\
\hline Royal Cleaners & 5865 Jarvis Ave & 94560 & 1996 & 18 \\
\hline Kim's Classic Cleaners & 6259 Jarvis Ave & 94560 & 1992 & 11 \\
\hline Sparkle One Hour Cleaners & 35284 Newark Blvd & 94560 & 1985 & 13 \\
\hline Complete Dry Cleaners & 5532 Thornton Ave & 94560 & 1986 & 17 \\
\hline Villa 1Hr Cleaners & 36565 Newark Blvd & 94560 & 1968 & 31 \\
\hline $\begin{array}{l}\text { Custom Commercial Dry } \\
\text { Cleaners }\end{array}$ & 37390A Cedar Blvd & 94560 & 1990 & 1 \\
\hline Country Club Cleaning Center & 35201 Newark Blvd, \#12 & 94560 & 1972 & 23 \\
\hline Delia's Cleaners & 5454C Central Ave & 94560 & 1987 & 4 \\
\hline Mowry Plaza Cleaners & 39123 Cedar Blvd & 94560 & 1985 & 6 \\
\hline Dry Clean Zone & 5766 Mowry School Rd & 94560 & 1987 & 22 \\
\hline Classic Cleaners & 6180 Jarvis Ave, \#Z & 94560 & 1988 & 26 \\
\hline $\begin{array}{l}\text { Lido-Faire Cleaners and shirt } \\
\text { laundry }\end{array}$ & 6101 Jarvis Av & 94560 & 1961 & 14 \\
\hline $\begin{array}{l}\text { Delia's cleaners and drapery } \\
\text { center }\end{array}$ & 35149 Newark Blvd & 94560 & 1987 & 7 \\
\hline Villa one hour cleaners & & & & 15 \\
\hline
\end{tabular}

Table A3. Union City dry cleaners likely to be or to have been plants

\begin{tabular}{|l|l|l|l|l|}
\hline business name & address & $\begin{array}{l}\text { zip } \\
\text { code }\end{array}$ & $\begin{array}{l}\text { year operation } \\
\text { began }\end{array}$ & $\begin{array}{l}\text { years of } \\
\text { operation }\end{array}$ \\
\hline US Cleaners & 34584 Alvarado-Niles Rd & 94587 & 1989 & 25 \\
\hline Quality Cleaners & 31864 Alvarado Blvd & 94587 & 1982 & 32 \\
\hline Save On 1 hours Cleaners & 34375 Alvarado-Niles Rd & 94587 & 1990 & 24 \\
\hline Rose Cleaners & 33366 Alvarado-Niles Rd & 94587 & 1990 & 18 \\
\hline American Cleaners & 31883 Alvarado Blvd & 94587 & 1977 & 24 \\
\hline Cross Complete Cleaners & 1806 Whipple Rd & 94587 & 1970 & 41 \\
\hline
\end{tabular}




\section{APPENDIX B. OLDER CLEANERS LOCATED AT STREET SEGMENT LEVEL}

Table B1. Older cleaners located at the street and street segment level.

\begin{tabular}{|c|c|c|c|c|c|c|}
\hline business name & address & city & zip code & $\begin{array}{l}\text { plant } \\
\text { status }\end{array}$ & $\begin{array}{l}\text { year } \\
\text { operation } \\
\text { began }\end{array}$ & $\begin{array}{l}\text { years of } \\
\text { operation }\end{array}$ \\
\hline $\begin{array}{l}\text { Henry Miller Cleaning } \\
\text { Service, Centerville }\end{array}$ & $\begin{array}{l}128 \text { S Main, } \\
\text { Centerville }\end{array}$ & Fremont & unknown & likely & 1949 & 10 \\
\hline Kerns cleaners & 4114 Fremont Hub & Fremont & unknown & likely & 1964 & 20 \\
\hline Irvington Cleaners & $\begin{array}{l}115 \mathrm{~N} \text { Broadway, } \\
\text { Irvington }\end{array}$ & Fremont & unknown & uncertain & 1956 & 3 \\
\hline $\begin{array}{l}\text { Irvington Lauderette } \\
\text { and Cleaners }\end{array}$ & $\begin{array}{l}125 \text { N Broadway, } \\
\text { Irvington }\end{array}$ & Fremont & unknown & uncertain & 1957 & 1 \\
\hline $\begin{array}{l}\text { State Tailors and } \\
\text { Cleaners, }\end{array}$ & $\begin{array}{l}\text { 346 Broadway, } \\
\text { Irvington }\end{array}$ & Fremont & unknown & uncertain & 1950 & 5 \\
\hline $\begin{array}{l}\text { Henry Miller Cleaning } \\
\text { Service and Niles } \\
\text { Cleaners and Dyers }\end{array}$ & $\begin{array}{l}114 \text { Central Ave } \\
\text { Centerville }\end{array}$ & Fremont & unknown & uncertain & 1945 & 2 \\
\hline $\begin{array}{l}\text { Henry Miller Cleaning } \\
\text { Service }\end{array}$ & 725 1st, Niles & Fremont & unknown & uncertain & 1957 & 2 \\
\hline $\begin{array}{l}\text { Glenmoor Center } \\
\text { Cleaners, Centerville }\end{array}$ & 343 Glenmoor Dr & Fremont & unknown & uncertain & 1956 & 3 \\
\hline $\begin{array}{l}\text { Glenmoor Center } \\
\text { Cleaners, Centerville }\end{array}$ & $\begin{array}{l}345 \text { Glenmoor Dr, } \\
\text { Centerville }\end{array}$ & Fremont & unknown & uncertain & 1955 & 1 \\
\hline $\begin{array}{l}\text { State Dry Cleaners and } \\
\text { Laundry, Centerville }\end{array}$ & $\begin{array}{l}\text { 161 S Main, } \\
\text { Centerville }\end{array}$ & Fremont & unknown & uncertain & 1955 & 1 \\
\hline Expert cleaners & $\begin{array}{l}175 \text { S Main, } \\
\text { Centerville }\end{array}$ & Fremont & unknown & uncertain & 1949 & 1 \\
\hline $\begin{array}{l}\text { Henry Miller Cleaning } \\
\text { Service, Niles Store }{ }^{1}\end{array}$ & 725 Main, Niles & Fremont & unknown & uncertain & 1946 & 11 \\
\hline $\begin{array}{l}\text { Lewis Cleaners and } \\
\text { Laundry }\end{array}$ & $5252 \mathrm{nd}$ & Fremont & unknown & uncertain & 1955 & 3 \\
\hline Township Cleaners & 125 Mission & Fremont & unknown & uncertain & 1954 & 5 \\
\hline Township Cleaners & $\begin{array}{l}137 \text { Mission, } \\
\text { Irvington }\end{array}$ & Fremont & unknown & uncertain & 1945 & 6 \\
\hline Orchard Park Cleaners & $\begin{array}{l}189 \text { Towers Wy, } \\
\text { Centerville }\end{array}$ & Fremont & unknown & uncertain & 1955 & 4 \\
\hline $\begin{array}{l}\text { Budget Cleaners, Lewis } \\
\text { Shopping Center }\end{array}$ & 871 Lincoln Rd & Newark & 94560 & uncertain & 1958 & 2 \\
\hline $\begin{array}{l}\text { Henry Miller Cleaning } \\
\text { Service }\end{array}$ & 2157 Thornton Ave & Newark & 94560 & uncertain & 1950 & 9 \\
\hline Econ-O-Wash & 7 Newark Sq & Newark & 94560 & uncertain & 1962 & 1 \\
\hline Newark Square cleaners & 17 Newark Sq & Newark & 94560 & uncertain & 1960 & 8 \\
\hline $\begin{array}{l}\text { Budget Cleaners, Lewis } \\
\text { Shopping Center }\end{array}$ & 1050 Granger Road & $\begin{array}{l}\text { Union } \\
\text { City }\end{array}$ & 94587 & uncertain & 1950 & 1 \\
\hline
\end{tabular}

1. Unable to locate on older street map 


\section{APPENDIX C. MAPS OF OLDER CLEANERS LOCATED AT THE STREET AND STREET SEGMENT LEVEL}

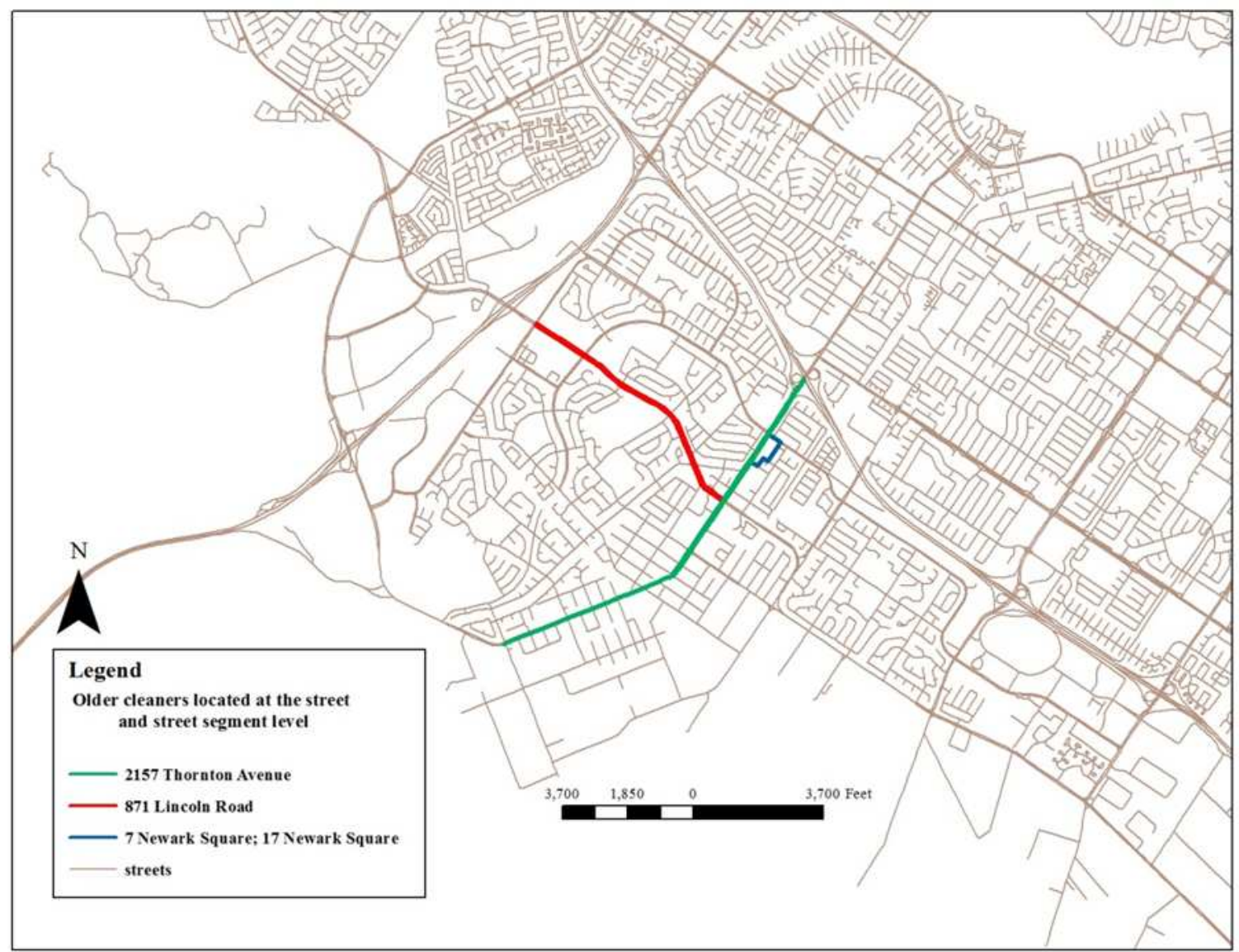

Figure C1. Older cleaners located at the street and street segment level in Newark (extracted from ESRI, 2010). 


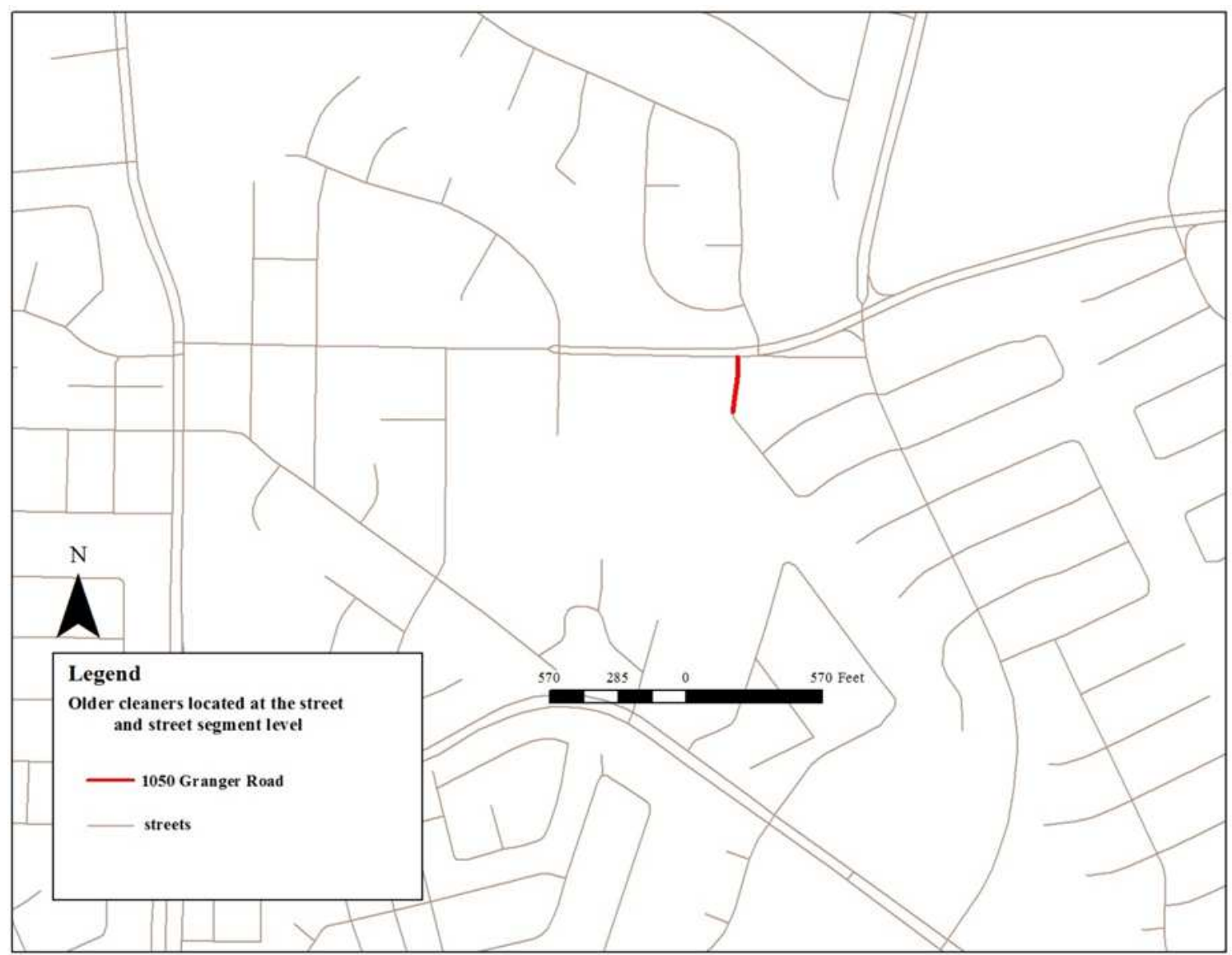

Figure C2. Older cleaner located at the street and street segment level in Union City (extracted from ESRI, 2010). 


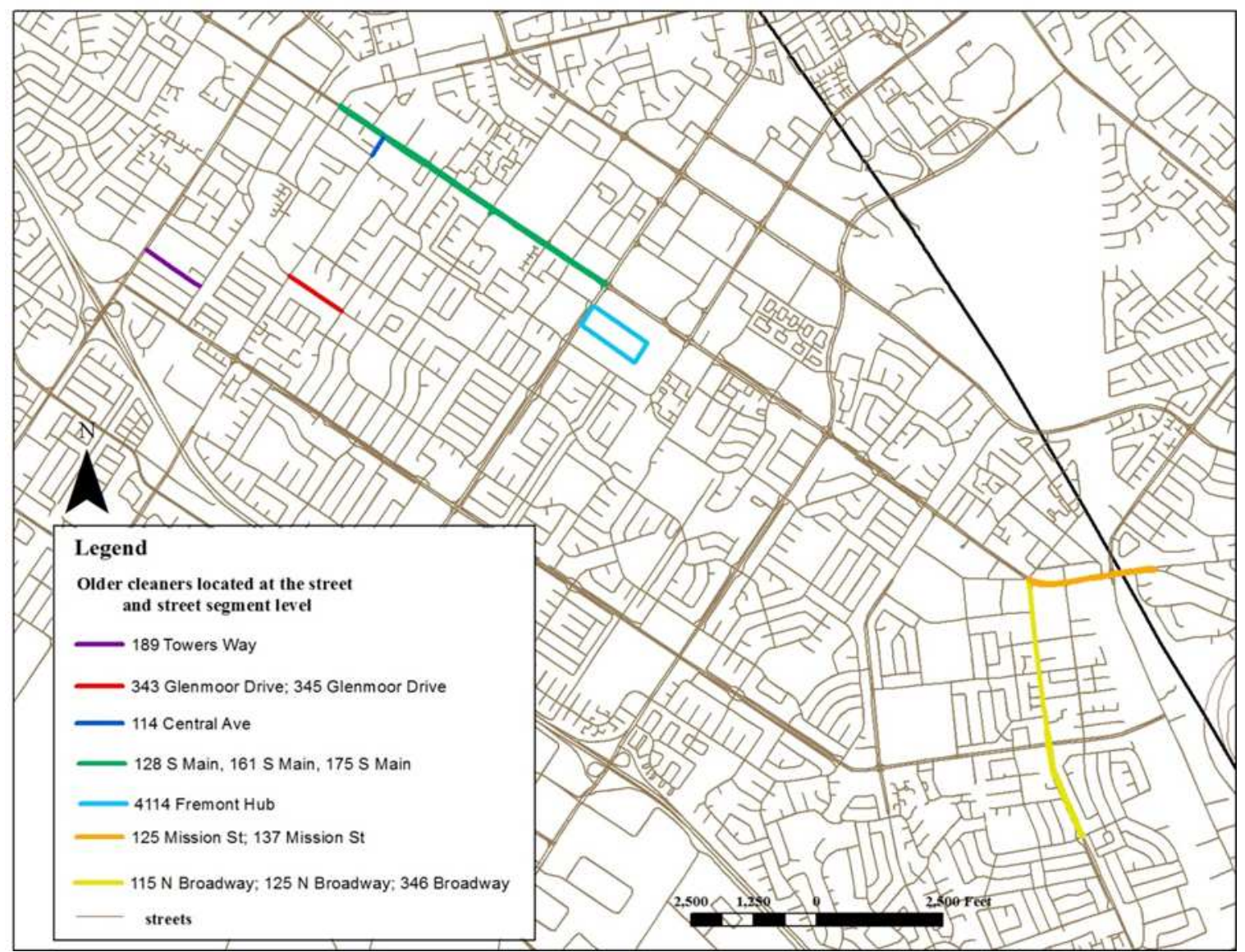

Figure C3. Older cleaners located at the street and street segment level in Fremont in BHF subbasin (extracted from ESRI, 2010). 


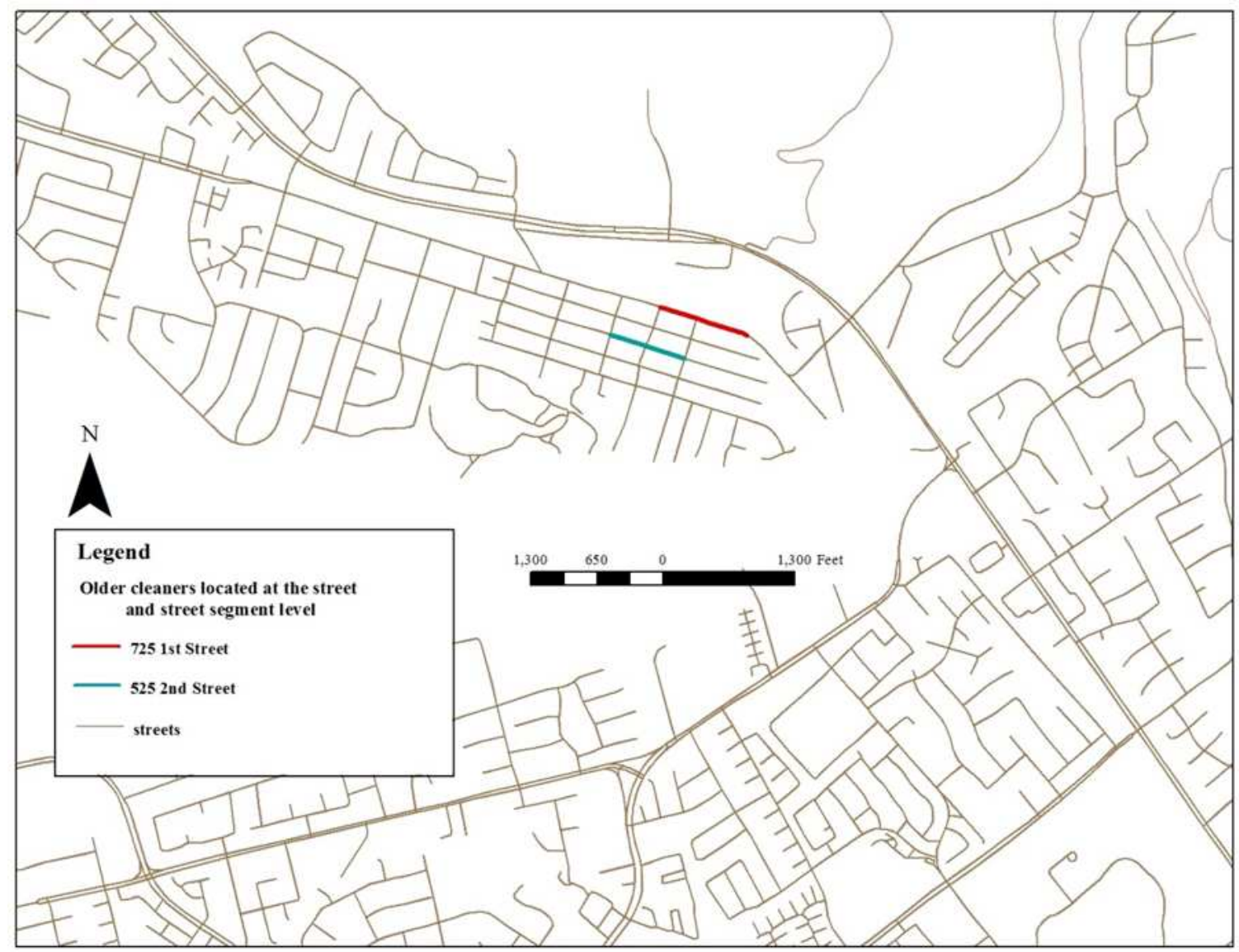

Figure C4. Older cleaners located at the street and street segment level in Fremont in AHF subbasin (extracted from ESRI, 2010). 


\section{APPENDIX D. DRY-CLEANING BUSINESSES FOR WHICH PLANT STATUS IS UNCERTAIN}

Table D1. Fremont dry cleaners for which plant status is uncertain.

\begin{tabular}{|c|c|c|c|c|}
\hline business name & address & zip code & $\begin{array}{l}\text { year operation } \\
\text { began }\end{array}$ & $\begin{array}{l}\text { years of } \\
\text { operation }\end{array}$ \\
\hline Niles Laundromat & $120 \mathrm{~J}$ Street & 94536 & 1958 & 2 \\
\hline Arrowhead cleaners & 3900 Lake Arrowhead Ave & 94555 & 1981 & 3 \\
\hline Speed-ease custm dry clng and lndry & 47471 Mantis & 94539 & 1987 & 1 \\
\hline Geri's alterations & 40733 Chapel Wy & 94538 & 2000 & 2 \\
\hline Fashion Center cleaners & 39147 Civic Center Dr & 94536 & 1988 & 3 \\
\hline Classique Dry Cleaners & 39370 Civic Center Dr & 94538 & 2005 & 7 \\
\hline Green Leaf Cleaners & 3918 Decoto Rd & 94555 & 2008 & 4 \\
\hline Township cleaners & 3800F Delaware Dr & 94538 & 1960 & 15 \\
\hline Bay Cleaners & 1940 Driscoll Rd & 94539 & 2003 & 9 \\
\hline So Fresh and Clean & 37803 Fernwood $\mathrm{Ct}$ & 94536 & 2002 & 10 \\
\hline Vogue Enterprise cleaners & 36464 Fremont Bl & 94536 & 1998 & 8 \\
\hline Sparkle Cleaner, Inc & 36488 Fremont B1 & 94536 & 2007 & 5 \\
\hline Mimo Alterations and cleaners & 37678 Fremont B1 & 94536 & 2007 & 5 \\
\hline Geri's cleaners/ Star Dry cleaners & 38487 Fremont Bl & 94536 & 1985 & 17 \\
\hline A A Cleaners & 39475 Fremont B1 & 94538 & 1993 & 1 \\
\hline Irvington Cleaners & 40967 Fremont B1 & 94538 & 1959 & 3 \\
\hline Payless cleaners/ Smart cleaners & 41025B Fremont B1 & 94538 & 1965 & 28 \\
\hline Smart cleaners & 41083 Fremont Bl & 94538 & 1993 & 19 \\
\hline Family Cleaners/ Crystal Cleaners & 42132 Blacow Rd & 94538 & 2004 & 4 \\
\hline Expressly Yours & 32955 Bluebird Loop & 94555 & 1991 & 2 \\
\hline Glenmoor Center Cleaners & 38228 Glenmoor Dr & 94536 & 1959 & 1 \\
\hline Jack Silva cleaners & 38440 Glenview Dr & 94536 & 1965 & 19 \\
\hline Sparkle shirts laundry & 44810 S Grimmer Blvd & 94538 & 1989 & 1 \\
\hline Niles City cleaners & 151 I Street & 94536 & 1964 & 8 \\
\hline Las Palmas Cleaners & 39969 Mission Blvd & 94539 & 1983 & 5 \\
\hline Mission Valley Cleaners & 39975 Mission Blvd & 94539 & 1974 & 3 \\
\hline Clean N Press for less & 43695 Mission Blvd & 94539 & 1997 & 1 \\
\hline Mission Hills cleaners & 43697 Mission Blvd & 94539 & 2007 & 1 \\
\hline Mission Hills cleaners & 36145 Niles Blvd & 94536 & 1989 & 2 \\
\hline Bargain Spot cleaners & 37337 Niles Blvd & 94536 & 1964 & 4 \\
\hline Township cleaners & 37573 Niles Blvd & 94536 & 1969 & 18 \\
\hline Montgomery Ward and Co & 4172 Ohna $\mathrm{Ct}$ & 94536 & 1975 & 1 \\
\hline Payless cleaners & 4165 Peralta Blvd & 94536 & 1962 & 21 \\
\hline Payless Cleaners & 3958 Peralta Blvd & 94536 & 1959 & 3 \\
\hline Park Lane French drapery cleaners & 4245 Peralta Blvd & 94536 & 1970 & 4 \\
\hline Pressed 4 Time & 33220 Pheasant & 94555 & 1991 & 3 \\
\hline Norge cleaners & 3767 Mowry Av & 94538 & 1990 & 5 \\
\hline Lewis L. Lewis & 332 Riverside Ave & 94536 & 1945 & 6 \\
\hline Parkway cleaners & 3909B Stevenson Blvd & 94538 & 1972 & 42 \\
\hline Plaza cleaners & 3622 Thornton Av & 94536 & 1989 & 3 \\
\hline Tri-City Cleaners & 37024 Towers Wy & 94536 & 1959 & 4 \\
\hline Walnut plaza lauderland & 3185 Walnut Av & 94538 & 1988 & 10 \\
\hline Pacific Cleaners & 4144 Walnut Av & 94538 & 2011 & 1 \\
\hline Vogue Dry cleaning Salon & 46850 Warm Springs Blvd & 94539 & 1966 & 27 \\
\hline Fremont Cleaners and Laundry & 656 Wasatch Dr & 94536 & 1958 & 2 \\
\hline Payless Cleaners & 3923 Washington Blvd & 94538 & 1962 & 1 \\
\hline Citidrycleaner & 3877 Wildflower Common & 94538 & 1991 & 2 \\
\hline Claridges Ltd & 44355 Auto Mall Cir & 94538 & 1978 & 1 \\
\hline
\end{tabular}


Table D2. Newark dry cleaners for which plant status is uncertain.

\begin{tabular}{|l|l|l|l|l|}
\hline business name & address & $\begin{array}{l}\text { zip } \\
\text { code }\end{array}$ & $\begin{array}{l}\text { year operation } \\
\text { began }\end{array}$ & $\begin{array}{l}\text { years of } \\
\text { operation }\end{array}$ \\
\hline Royal Cleaners & 5861 Jarvis Ave & 94560 & 1992 & 4 \\
\hline Haymont cleaners & 36746 Cedar B1 & 94560 & 1991 & 4 \\
\hline Courtesy cleaners & 7000D Jarvis Av & 94560 & 1967 & 1 \\
\hline Budget cleaners & 36601 Newark Blvd & 94560 & 1967 & 13 \\
\hline Henry Miller Cleaning Service & 7355 Thornton Avenue & 94560 & 1950 & 1 \\
\hline Payless cleaners & 5632 Thornton Av & 94560 & 1977 & 9 \\
\hline Fremont French cleaners & 36782 Cedar B1 & 94560 & 1973 & 1 \\
\hline Fremont cleaners and laundry & 37271 Cedar B1 & 94560 & 1960 & 1 \\
\hline Coit Drapery and Carpet Cleaners & 37366 Filbert & 94560 & 1975 & 4 \\
\hline Payless cleaners & 36925 Sycamore Rd & 94560 & 1961 & 12 \\
\hline
\end{tabular}

Table D3. Union City dry cleaners for which plant status is uncertain.

\begin{tabular}{|l|l|l|l|l|}
\hline business name & address & $\begin{array}{l}\text { zip } \\
\text { code }\end{array}$ & $\begin{array}{l}\text { year operation } \\
\text { began }\end{array}$ & $\begin{array}{l}\text { years of } \\
\text { operation }\end{array}$ \\
\hline Crystal Cleaners & 32144 Alvarado Blvd & 94587 & 1990 & 5 \\
\hline Sunflower European Cleaners & 32647 Alvarado Blvd & 94587 & 1988 & 1 \\
\hline Blue Sky Cleaners & 32920 Alvarado-Niles Road & 94587 & 2007 & 5 \\
\hline State Cleaners & 33902 Alvarado-Niles Road & 94587 & 1968 & 24 \\
\hline El Mercado Dry Cleaners & 34300 Alvarado-Niles Road & 94587 & 1982 & 19 \\
\hline Kim's Cleaners & 34547 Alvarado-Niles Road & 94587 & 1987 & 6 \\
\hline Delia's Cleaners & 34700 Alvarado-Niles Road & 94587 & 1991 & 23 \\
\hline S K Cleaners & 109 Appian Way & 94587 & 1987 & 3 \\
\hline Wash \& Fold Laundry & 109 Aurora Plaza & 94587 & 2007 & 1 \\
\hline Smart Dry Cleaner & 4112 Dyer Street & 94587 & 1993 & 21 \\
\hline Johnny's Cleaners & 605 E St & 94587 & 1956 & 7 \\
\hline Price Rite Cleaners & 607 E St & 94587 & 1971 & 1 \\
\hline A\&B Dry Cleaning & 33427 Mission Blvd & 94587 & 1967 & 1 \\
\hline Ray's Cleaners / Ace Cleaners & 1790 Decoto Road & 94587 & 1976 & 14 \\
\hline T \& J Equipment and Supplies & 1659 Whipple Road & 94544 & 1997 & 1 \\
\hline
\end{tabular}




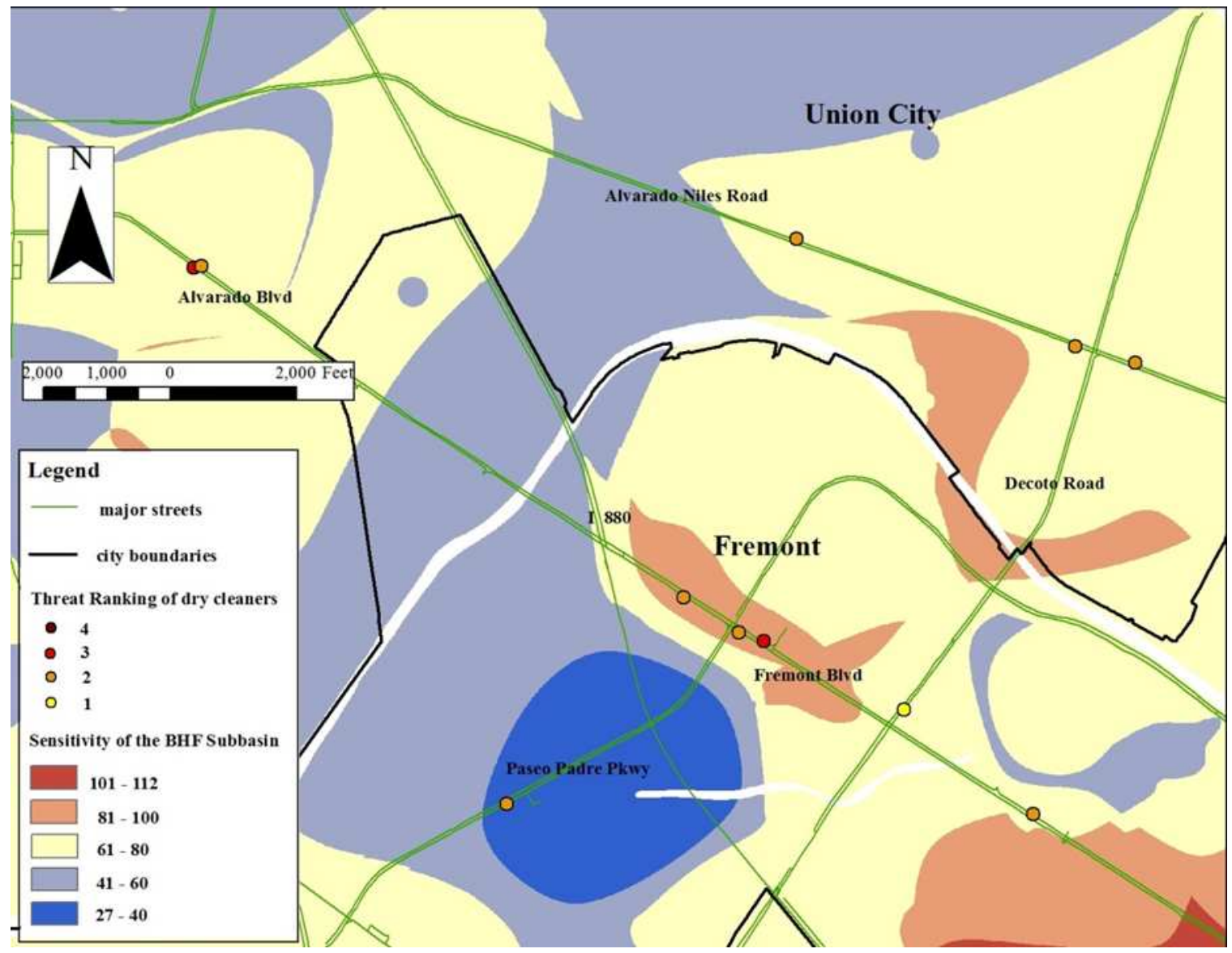

Figure E1. Vulnerability map of the upper third of the BHF subbasin (extracted from ESRI, 2010; Alameda County CDA, 2012). 


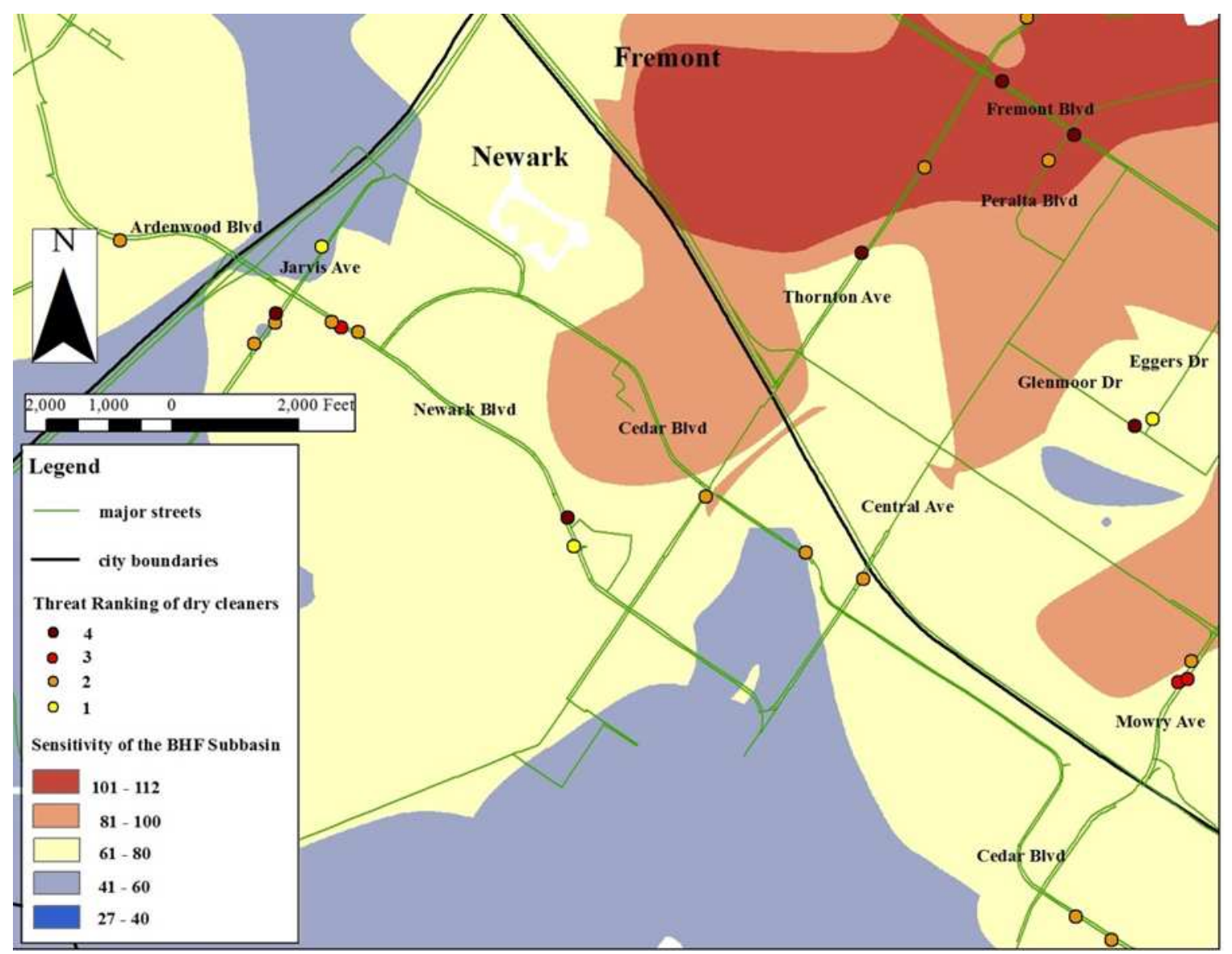

Figure E2. Vulnerability map of the middle third of the BHF subbasin (extracted from ESRI, 2010; Alameda County CDA, 2012). 


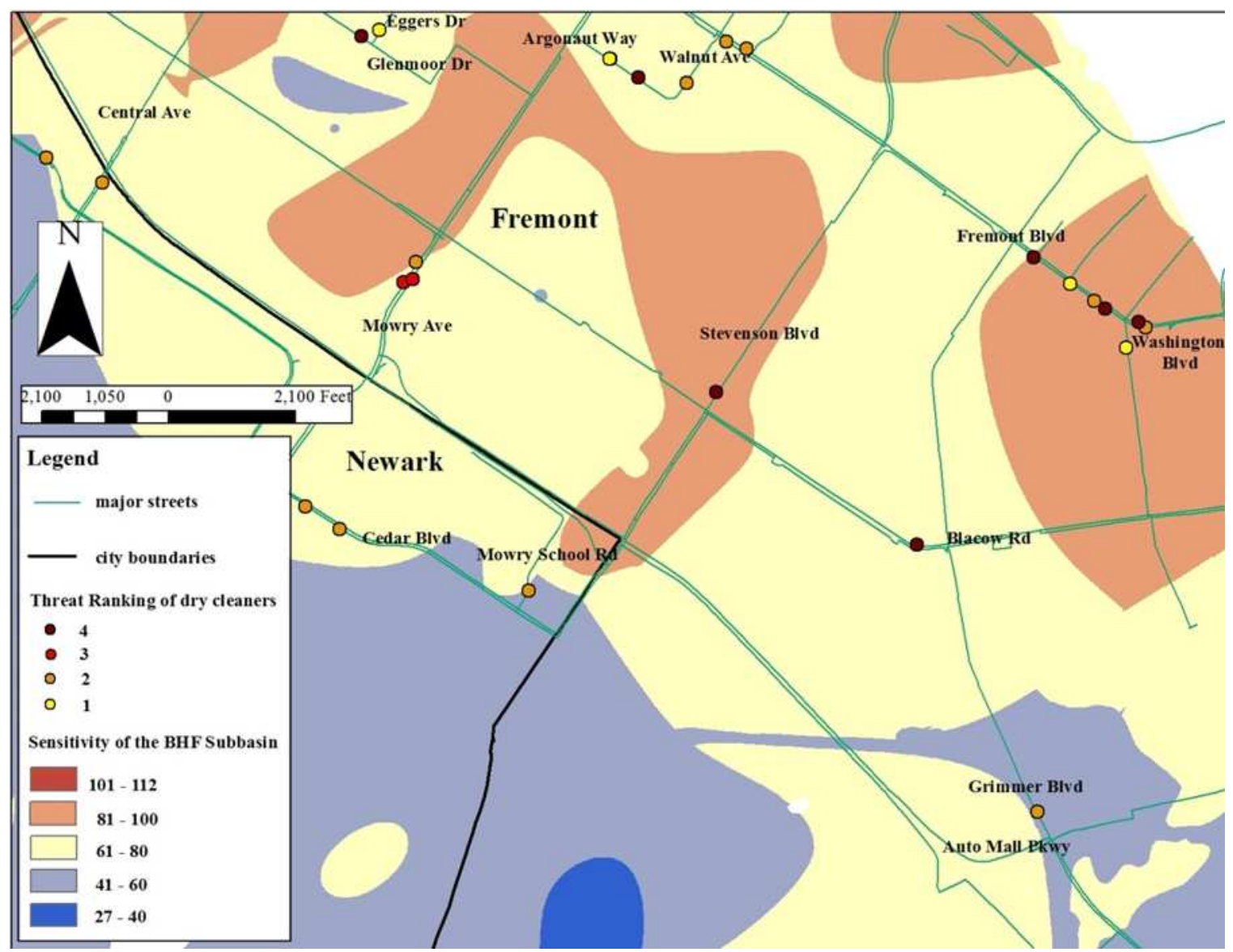

Figure E3. Vulnerability map of the lower third of the BHF subbasin (extracted from ESRI, 2010; Alameda County CDA, 2012). 


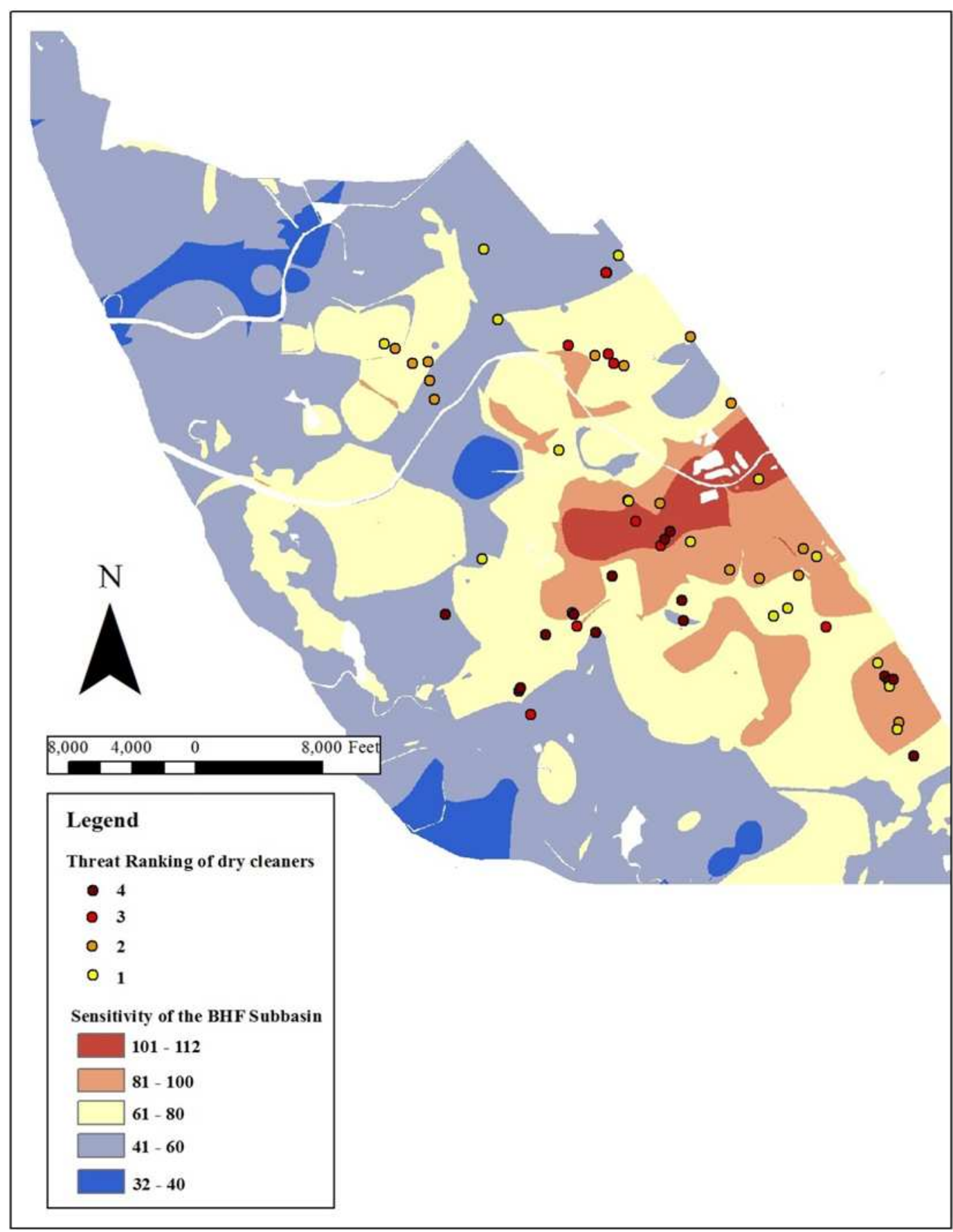

Figure F1. Vulnerability map of the BHF subbasin based on cleaners for which the plant status is uncertain. 


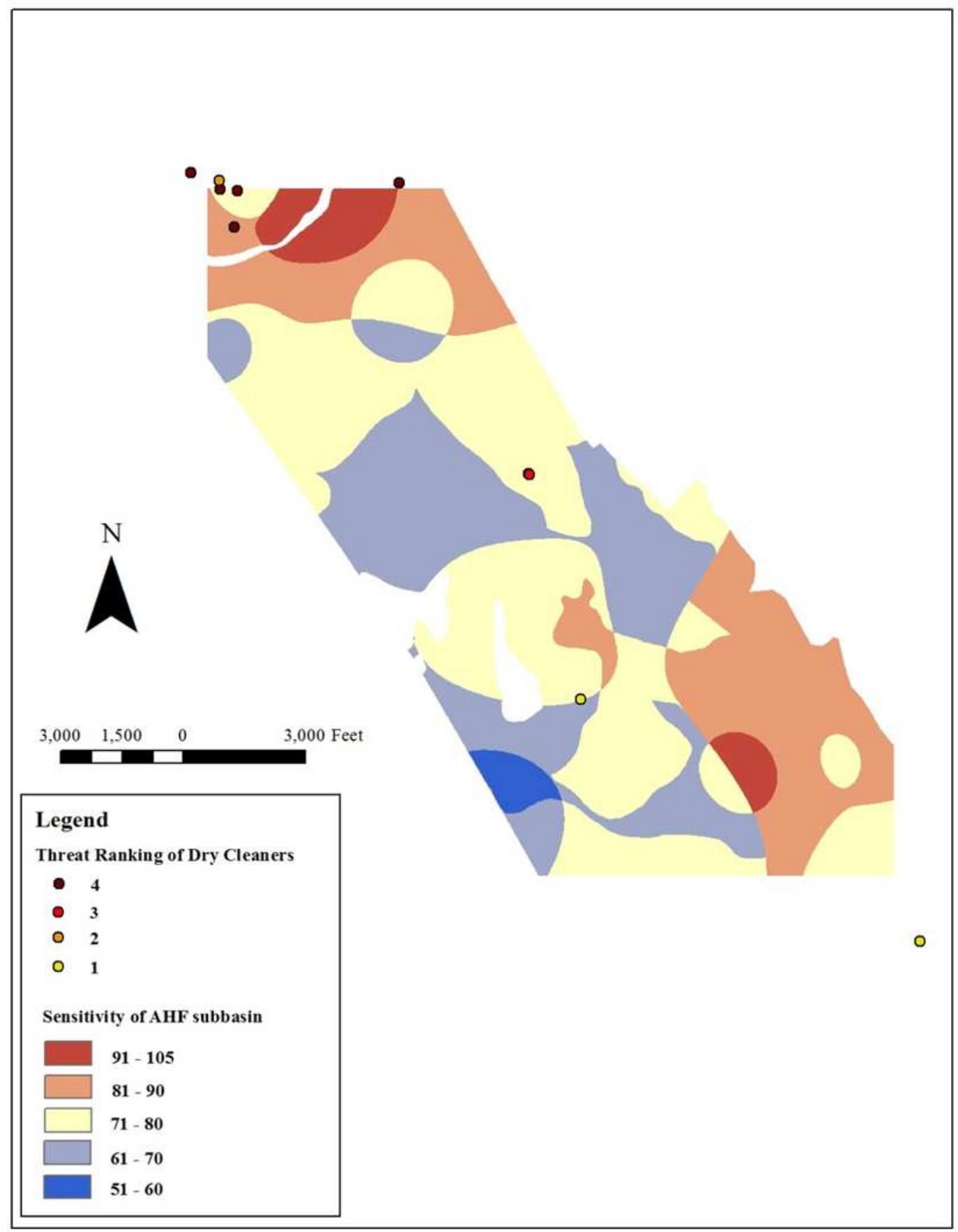

Figure F2. Vulnerability map of the AHF subbasin based on cleaners for which the plant status is uncertain. 